\title{
Jens Holdt: Brede sogn under besættelsen
}

\author{
ved Henrik Skov Kristensen
}

I besattelsesårene 1940-45 førte pastor Jens Holdt i Brede dagbog over store og små begivenheder $\mathrm{i}$ sit sogn. Senere bearbejdede han dagbogen med henblik på udgivelse. Beretningen givet et sjældent indblik $\mathrm{i}$ livet $\mathrm{i}$ et nordslesvisk landsogn $\mathrm{i}$ krigsårene. Især fortæller den senere provst meget åbenhjertigt om forholdet mellem de danske og hjemmetyskerne og om de danske nazister. Man holdt virkelig øje med hinanden i de »fem forbandede år«.

Om Jens Holdt og hans skildring af Brede sogn 1940-45

Jens Holdt, dr. theol. blev født den 24. dec. 1895 i Raved, Bjolderup sogn. Han virkede som sogneprest i Brede fra 1925 til 1963, og fra 1951 til 1963 var han provst for Tønder provsti.

Jens Holdt er forfatter til adskillige afhandlinger om sønderjysk ånds- og kirkehistorie, og var i en årrække medlem af styrelsen for Historisk Samfund for Sønderjylland.

Nærværende skildring af Brede sogn under besættelsen havde Holdt også tænkt sig offentliggjort. Manuskriptet, som bygger på Holdts dagbogsoptegnelser, er udarbejdet midt i 60'erne, hvor Holdt sendte det til Sønderjysk Månedsskrift. Senere, i 70'erne, tilgik det Sønderjyske Årbøger. Når manuskriptet, som her bringes $\mathrm{i}$ lettere redigeret form, ikke allerede da blev publiceret, skyldes det uden tvivl dets kontroversielle indhold: Udover, som andre typiske dagbøger fra besattelsen, at være en kalender over lokale dramatiske tildragelser med enkelte udblik til store begivenheder uden for lokalområdet, kaster Holdts skildring lys over forholdet mellem danske og tysksindede i Brede sogn. Fra sin udkigspost har Holdt $\mathrm{i}$ dagbogens lapidariske og ikke mindst åbenhjertige form fastholdt spændingerne mellem de to grupper. Også de danske nazister, som generelt stod stærkt i Nordslesvig, er genstand for Holdts opmærksomhed, og undertiden falder det vanskeligt at skelne dem fra hjemmetyskerne. Begge grupperinger var under alle omstændigheder på den forkerte side $\mathrm{i}$ den nationale sindelagskamp, som er et gennemgående tema i Holdts skildring. Intet dølges. Heller ikke navne. Når vi har valgt at bringe manuskriptet forholdsvist uredigeret - $\mathrm{i}$ et enkelt tilfælde har vi dog valgt at sløre et gennemgående familienavn - skyldes det ikke trangen til at tilfredsstille en evt. nyfigenhed, men fordi det (mis)forhold, som Holdt skildrer, ganske troligt vil kun- 


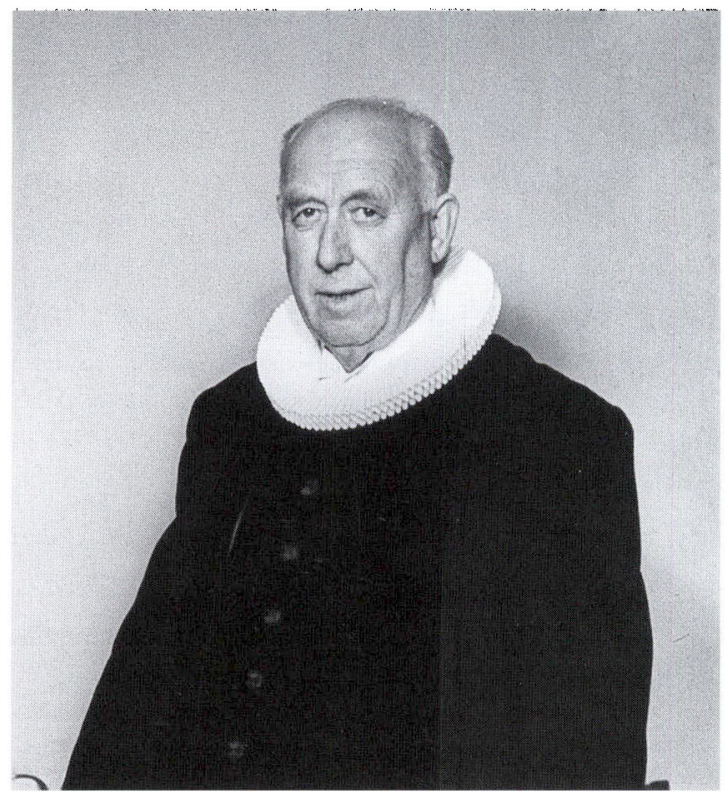

Jens Holdt (1895-1967) var sogneprest $i$ Brede 1925-63 og tillige provst for Tonder provsti fra 195I. Han blev dr. theol. $i 1937$. Foto 1960 i Lokalhistorisk Samling, Bredebro.

ne genfindes i andre nordslesvigske sogne. Derved rakker Holdts skildring ud over det rent lokale.

Holdt lægger ikke fingrene imellem i sin skildring af nazificeringen af hjemmetyskerne. Undertiden bærer hans iagttagelser nærmest smålighedens præg, og selv bagateller noteres sirligt. Det i sig selv fortæller en del om modsætningerne mellem danske og tysksindede. Til gengald hudfletter Holdt lige så voldsomt retsopgøret med det tyske mindretal. Han finder opgøret uklogt, småligt og chauvinistisk.

Uden nogen tvivl betræes med Holdts skildring et tabu-belagt område. I de senere år har man imidlertid kunnet spore en større beredvillighed til at få ovennævnte forhold bearbejdet. F.eks. har det tyske mindretal ytret ønske om at få Fårhuslejren belyst. Nogle, danske som hjemmetyske, vil sikkert mene, at Holdts skildring skulle være blevet i skuffen. Men skal man belyse forholdet mellem danske og hjemmetyske under besættelsen og det efterfølgende retsopgør, undgår man ikke, hvad nogle vil opfatte som indiskretioner.

Et andet hovedtema i Holdts skildring er kirkens placering i forhold til øvrigheden, herunder selvfølgelig også hvordan han selv placerede sig. Også i det spørgsmål er Holdt en sammensat person. Den danske folkekirke generelt var en fast støtte for den danske regerings samarbejds- og forhandlingspolitik overfor tyskerne. Et væsentligt element i legitimeringen af denne politiske kurs 
var den nationale samling: man måtte samles om alt dansk og undgå at blive rendt over ende af den tyske kultur. Alle måtte vise en "værdig national holdning «. Det indebar bl.a., at man sluttede op om parolen om »ro og orden«. Denne holdning tilsluttede Holdt sig grundlæggende. Men for ham var der en grænse i forhold til øvrighedens og gejstlige foresattes bud: præsterne skulle frem for alt være sandhedsvidner, og kom man til at lide for sandhedens skyld, var det ingen skade, men netop situationens krav.

Dette grundsynspunkt bragte Holdt i konflikt med biskop Scharling i Ribe, som nærmest personificerede den danske folkekirkes overvejende forsigtige linie. Scharling karakteriserede præstegården i Brede som mén af stiftets tre urocentre«. Sandt er det, at Holdt hørte til de forholdsvis få »aktivistiske« præster, som hovedsageligt kom fra den kirkepolitiske højreflø. Men modsat en del af sine mere aktivistiske kolleger, greb Holdt aldrig til væbnet modstand. I en upubliceret levnedsbeskrivelse skriver Holdt: »I det hele taget var det mig om at gøre at understrege sandhedens og rettens kristne begrundelse i den danske modstand mod nazismens herrevælde. Men for mit vedkommende måtte modstanden ske med ordets åndelige sværd og ikke med voldelige midler - uden at jeg dog ville sætte mig til dommer over andre, der gik ind for militær partisankamp«.

Til grund for denne holdning lå uden tvivl Holdts pacifistiske indstilling. Han var stærkt præget af de grusomme oplevelser i 1. Verdenskrigs skyttegrave. Holdts pacifistiske og anti-nationalistiske holdninger bevirkede, at han efter 2. verdenskrig blev kendt som »den røde provst«. En usædvanlig betegnelse for en mand der med sin missionske baggrund nærmest var konservativ i troen og i gudsforholdet. Egentlig overbevist socialist var han nok ikke, men hans radikale pacifisme og anti-nationalisme placerede ham ikke desto mindre på den venstrefløj, som under den kolde krig så den vestlige, kapitalistiske verden som den største trussel mod verdensfreden.

\section{$* * *$}

Brede sogn under besættelsen

En dokumentarisk skildring

Den tyske besættelse af Danmark 1940-45 kaldte på dansk-national holdning og folkeligt sammenhold. På grundlag af egne dagbogsoptegnelser fra disse bevægede krigsår skal jeg forsøge at skildre stemninger og tilstande i Brede sogn i dette tidsrum.

Dette mellemstore landsogn på godt 5.000 ha med omved 1700 indbyggere har en vis central beliggenhed i Vestslesvig ved broen over Brede å. Den vestlige 


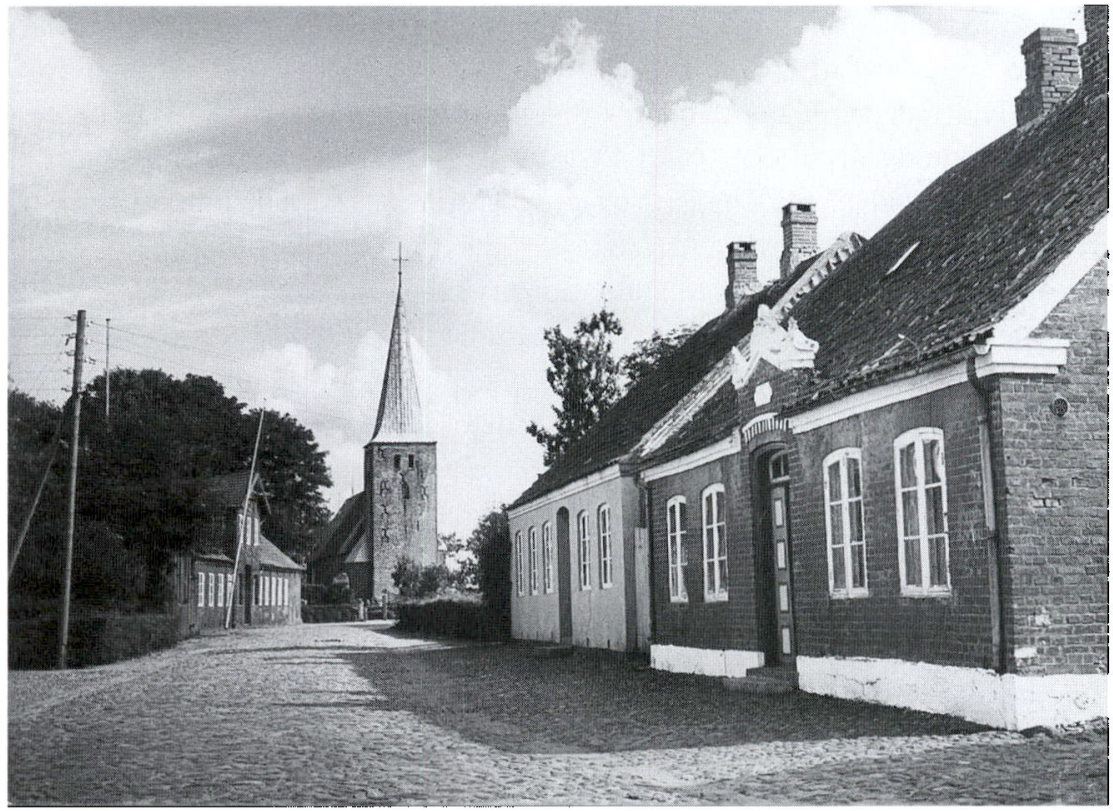

Kirkegade i Bredebro med kirken i baggrunden. Foto for 1960 i Institut for sonderjysk Lokalhistorie.

hovedvej og jernbanen syd-nord krydses her af vest-østgående veje. Vi befinder os på et trafikknudepunkt fra Arilds tid.

Den østlige fjerdedel af sognet med kirkens kampestenshus, bygget omkring år 1200 ved vadestedet, hørte indtil 1850 under Slesvig, medens de øvrige tre fjerdedele indtil udskiftningen i slutningen af det 18. århundrede havde hørt under Trøjborg gods. Det gav sognet det overvejende danske grundpræg. I 1907 fik man forsamlingshus, og i 1912 holdtes det danske årsmøde her. Ved afstemningen i 1920 var der $85 \%$ danske stemmer. I tysk tid havde der været en månedlig tysk bigudstjeneste, som den nuværende tyske frimenighedspræst i Løgumkloster efter nazismens frembrud i 30'erne søgte at genoplive, men forgæves.

Landbrugskrisen i 30 'erne medførte ingen tvangsauktion i sognet. Men nazismens udfordring med krav om grænserevision skabte dansk samling og aktivering af forsamlingshusarbejdet. Det Unge Grænseværn vandt stor tilslutning på stedet. Mejeribestyrer H.Lorentzen, Bredebro, der havde været formand for ungdomsforeningen i 20 'erne, blev dets næstformand. Sognepræsten J. Holdt var een af talerne ved Dybbølstævnet 11/6 1933. Ved det betydningsfulde rigsdagsvalg $3 / 439$ var der i Brede sogn $82,3 \%$ danske stemmer, heraf $8 \%$ på det danske nazistparti DNSAP, og 5,3\% tyske. ${ }^{1}$ 
Efter Hitler-Tysklands overfald på Polen 1/9 39 og den påfølgende krigstilstand med England og Frankrig og den fortsatte krigsforberedelse måtte også Danmark ved Østersøens indfaldsveje - trods den bestående ikke-angrebspagt - være belavet på alt.

\section{0}

I de første måneder af 1940 havde vi indkvartering af mindre danske troppestyrker, som jævnligt holdt øvelser i terrænet. Men de blev trukket nord på, ligesom garnisonen i Tønder, hvor der kun blev en maskingeværskole tilbage til lidt militær sikring af grænsen ud over gendarmeriet.

Vinteren var streng og varede længe. En kold påske blev overstået. 8/4 hørte vi $i$ radioen om et tysk troppe-transportskibs torpedering i Skagerrak og spurgte os selv, om det var på vej mod England - eller hvorhen ellers? Norge tænkte vi vist egentlig ikke på. Der meldtes også om tyske troppebevægelser op mod den danske grænse - til forsvar mod engelsk landgang i Esbjerg eller hvad ellers? Der var i hvert fald spænding i luften. Men Danmark var vel ikke i fare?

\section{Den 9. april}

I præstegården i Brede by vest for jernbanen og hovedvejen lå soveværelserne ovenpå, børnenes mod øst. K1. ca. 5.30-6 vækkede de os og meddelte forskrækket, at der var fyldt med flyvere over byen. Vi kom hurtigt på benene og i tøjet. Store sorte "fugle«, bombere og jagere, med hagekorsmærke brusede lavt hen over byen i nordlig og sydlig retning, følgende vej og jernbane. Der var ingen tvivl. Tyskerne var undervejs. Var det nu Nordslesvigs skæbnetime efter alle de andre Versailles-grænselandes? ${ }^{2}$

I retning af Sølsted mod syd sås fly-manøvrering. Og snart fik vi sandheden brutalt at vide ved læsningen af de nedkastede flyvesedler, general Kaupisch's »Oprop« om, at Det tyske Rige havde taget hele Danmark under sin »beskyttelse«, så længe krigen varede.

Jeg gik en tur ned i byen for se og høre nyt. Gaderne var tomme. Jeg var på mejeriet og talte med Lorentzens. Følelserne og ordene var ikke blide. Vi vidste ikke noget om, at maskingeværskolen fra Tønder, ca. 25 mand under kaptajnløjtnant Lauersens kommando, på motorcykler havde trukket sig nord på foran de tyske panserkolonner. De havde været i stilling og skudt på de fremrykkende tyskere syd for Sølsted og var nu posterede ved sydindgangen til Bredebro bag barrikaderet hovedvej, men med hovedstyrken i Svanstrup skov lige nord for broen, som ligeledes var blevet nødtørftigt spærret med 


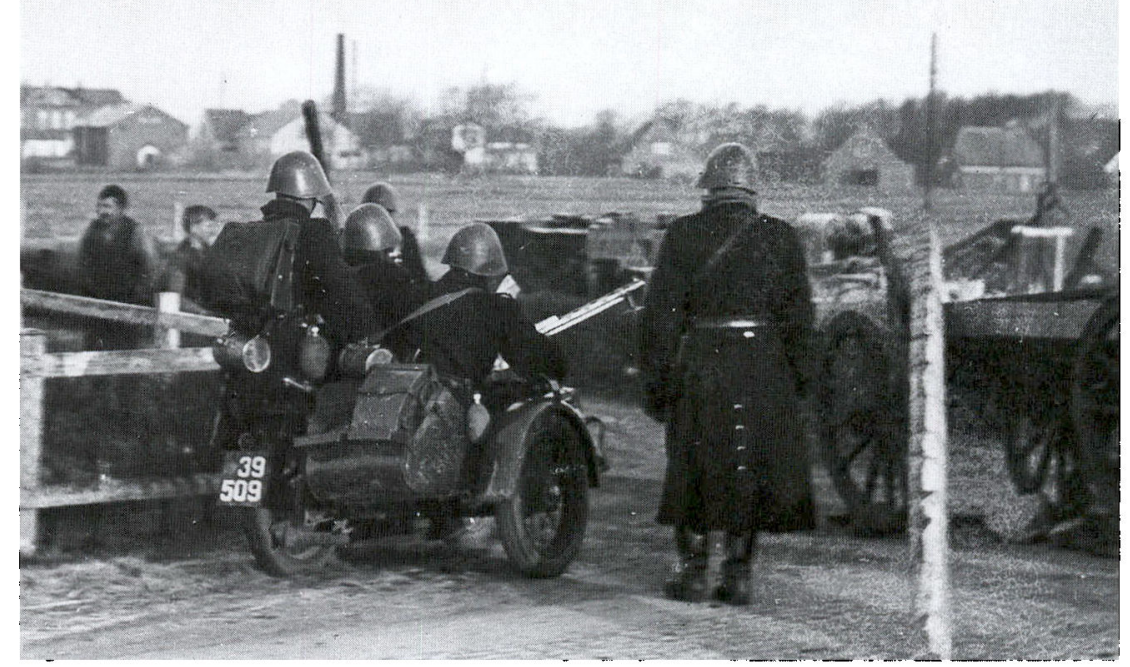

Danske soldater $i$ stilling på Borgvej syd for Bredebro den 9. april 1940. Foto: Lokalhistorisk Samling. Bredebro.

nogle arbejdsvogne. Men på hjemvejen, kl. ca. 7, begyndte kuglerne fra luften at pibe ned $\mathrm{i}$ byens gader. Et skyderi var $\mathrm{i}$ gang et kvarters tid eller så. Jeg mødte mælkevognen fra Brede på vej til mejeriet og hjalp kusken Laurids Lauridsen med at få hestene spændt fra vognen og bragt hjem, ligeså enkelte skolebørn på vej til skolen i Bredebro. Som gammel krigsdeltager sagde jeg til dem: »Dette her er farligt. Nu gælder det om at komme i hus og ikke være nysgerrig«. - Under skudvekslingen mellem danske og tyske maskingeværer ved byens sydlige indgang ramtes skolens sydmur af tyske kugler.

Siden, kl. ca. 9, erfarede vi, at tyske tropper var i Bredebro (2. panserdivision fra Stettin). Jeg gik derned og ind til købmand Gantzel på »Stjernen«. Panserkolonnen fyldte hele gaden syd-nord $\mathrm{i}$ højre vejside. Vi undlod at tale med soldaterne, men fik at vide, at de var blevet standsede af »Heckenschützen« $\mathrm{i}$ byens sydlige udkant. De danske skytter var nu afvæbnede og under bevogtning i Svanstrup skov. Henne ved købmand Brodersen fik tyskerne »Liebesgaben«, så vi. Pludselig kom en hjemmetysk gårdejer (Ludolph A. Jessen) fra Åspe, tværs over pladsen hen til Gantzels dør og råbte: „God morgen, hr pastor, nu er Hitler kommet ind i Nordslesvig, og han går aldrig mere ud igen, jeg vidste det allerede $\mathrm{i}$ aftes« (!), hvorpå han gav mig hånden. Jeg svarede, at 


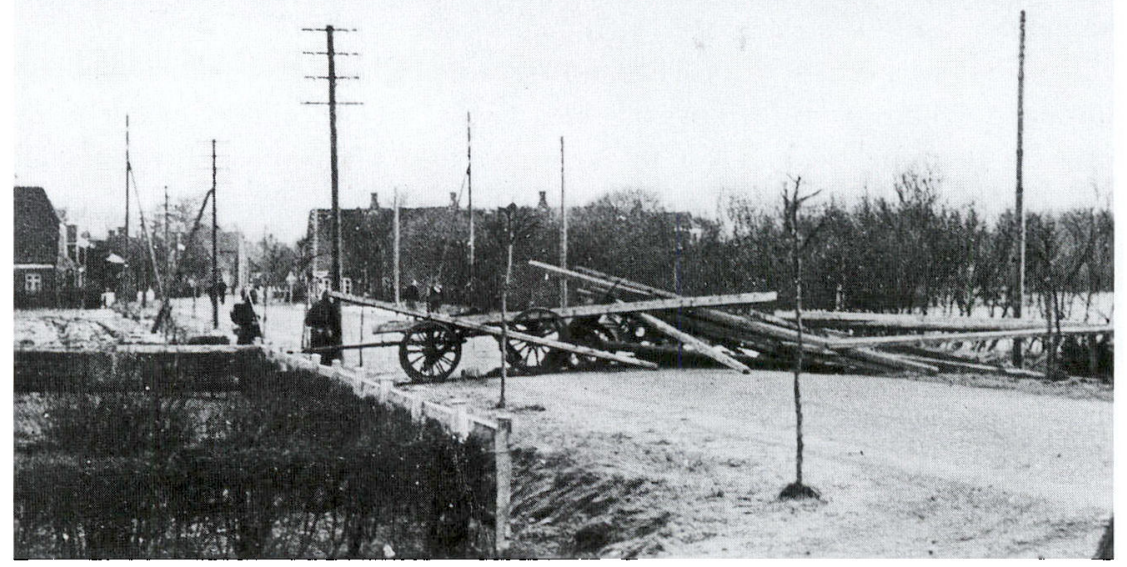

Der er etableret vejsparring mod tyskerne i Sondergade i Bredebro den 9. april 1940. Foto: Lokalhistorisk Samling, Bredebro.

jeg regnede med, at Hitler forlod landet igen, hvorpå der udspandt sig et mindre ordskifte, der endte med, at vi væddede for og imod. Gantzel trak nu præsten ind af døren. Man skulle ikke diskutere med tyskerne nu, mente han med rette.

Der fortaltes så, at også kirken var brudt op. Jeg gik derop for at se, hvad der var sket. Kirkedøren stod åben. En fodliste var brudt af, men ellers var den tunge dør ubeskadiget. Jeg gik ind i kirken og op til alteret for at se, om der ellers var ødelagt noget. Det var der ikke. Da jeg kom ud af døren igen, kom en tysk underofficer springende over gravene og spurgte ophidset på tysk, hvad jeg ville i kirken. Jeg svarede roligt på tysk, at jeg var præsten på stedet, som havde ansvaret for kirken, hvis dør var brudt op. Han forklarede da, at de havde kirken under observation, »fordi vi er blevet beskudt fra kirketårnet. Lige før Dem gik to mænd med blå kasketter ind i kirken, de er ikke kommet ud igen. Så gik De derind og kom atter ud«. Jeg svarede, at de to nævnte mænd, der var kommet fra Trelborg over kirkestien, ikke var i kirken. Dem havde jeg truffet nede i kirkegaden. Det ville han ikke tro. "Det vil vi undersøge«, fortsatte han, og kaldte på en menig med maskinpistol. Han fik ordre til at stå skudklar foran døren. „Vi har vore erfaringer fra Polen«, føjede han til, »hvor vi også blev beskudt fra kirketårne«. Jeg tilbød at gå med ind i kirken. Det afslog han. Forsigtighed var påbudt. Han ville gå selv, bevæbnet naturligvis, og nu op i tårnet, hvor der stadig ses småhuller af revolverkugler i væggen. Nogen tid efter kom han tilbage. Han havde ingen danskere fundet, 
og sendte så sin fælle bort igen. Også jeg gik ned i gaden igen. Ophidselsen var naturligvis forklarlig. Som fjende i et fremmed land er man aldrig tryg ved baghold.

Det viste sig siden, at den i sin tid fra Hannover til Sommersted indvandrede husmand Willms, som for kort tid siden havde købt en mindre ejendom lige over for Bredebro skole, havde fyldt i tyskerne, at præsten eller kirketjeneren havde udleveret kirkenøglen til de danske soldater, som så fra tårnets glamhuller havde skudt på de fremrykkende tyskere på hovedvejen syd fra. Det var imidlertid ondsindet opspind. Sandheden var, at de danske soldater ikke havde været i kirken eller på kirkegården. Et par af dem var, efter skyderi, blevet afvæbnede $\mathrm{i}$ og ved kirkegaden, fortalte deres leder mig siden, de øvrige $\mathrm{i}$ Svanstrup skov, besat kl. 7, af øst fra kommende tyske afdelinger, der havde omgået den danske retræte. De havde da også stillet et par maskingeværer op på marken nord for åen og beskudt kirketårnet fra nord, særlig glamhullerne mod nord, med ca. 100 skud. Klokkestolen i tårnet og gelænderet i tårnopgangen mod nord bærer den dag i dag skudmærker fra denne beskydning. Også spirets nederste blyplader blev gennemhullede. Disse tyske kugler har enkeltvis også fundet vej syd over til de derværende tyske afdelinger på hovedvejen. Man besluttede da, med en antitankkanon, at beskyde kirketårnet syd fra. "Nur ein Schuss«, lød kommandoen. Denne granat ramte ikke tårnet, men kirkeskibets mur under vindueshøjde, borede sig i et armtykt hul gennem murens ydre skal mellem to kvadre, men heldigvis uden at eksplodere. Den ligger endnu inde i murens hulrum. Hullet er siden tilmuret.

Også selve byen var hin morgen blevet beskudt med granater, af hvilke nogle heller ikke eksploderede. Dagen efter mødte jeg bager Alfred Petersen, som da tog to små granater op af lommen. Dem havde han samlet op på gaden.

Søren Clausen, Svanstrup havde et sammenstød med tyske soldater, der påstod, at der var blevet skudt fra hans gård. Da han afviste dette og udtalte, at "vi ikke havde haft bud efter dem«, ville man arrestere ham, men undlod det. En salve fra en flyvemaskine gennemhullede samme morgen tagvinduet $i$ skræder Th. Winds to-etages hus i Bredebro. Men lærlingen, der havde sit kammer under det ramte tag, blev heldigvis ikke selv ramt. I Brede fandt man i vaskerummet mod nord hos arbejdsmand Karl Lassen lige nord for præstegården en geværkugle og en udenfor i haven, som heller ikke havde ramt nogen. Der var ingen sårede $\mathrm{i}$ byen, hverken blandt civilbefolkningen eller militæret.

I Sølsted blev en kone, fru Hjort, boende overfor kroen og det nye forsamlingshus, såret af et skud eller en granatsplint. Om eventuelle tyske tab vides intet. Der blev sagt at to var sårede.

Da hovedvejen nu var fri nord på, fortsatte den tyske kolonne uhindret $\mathrm{i}$ retning af Ribe og Esbjerg. Det siges, at man havde hjemmetyske motorcyk- 


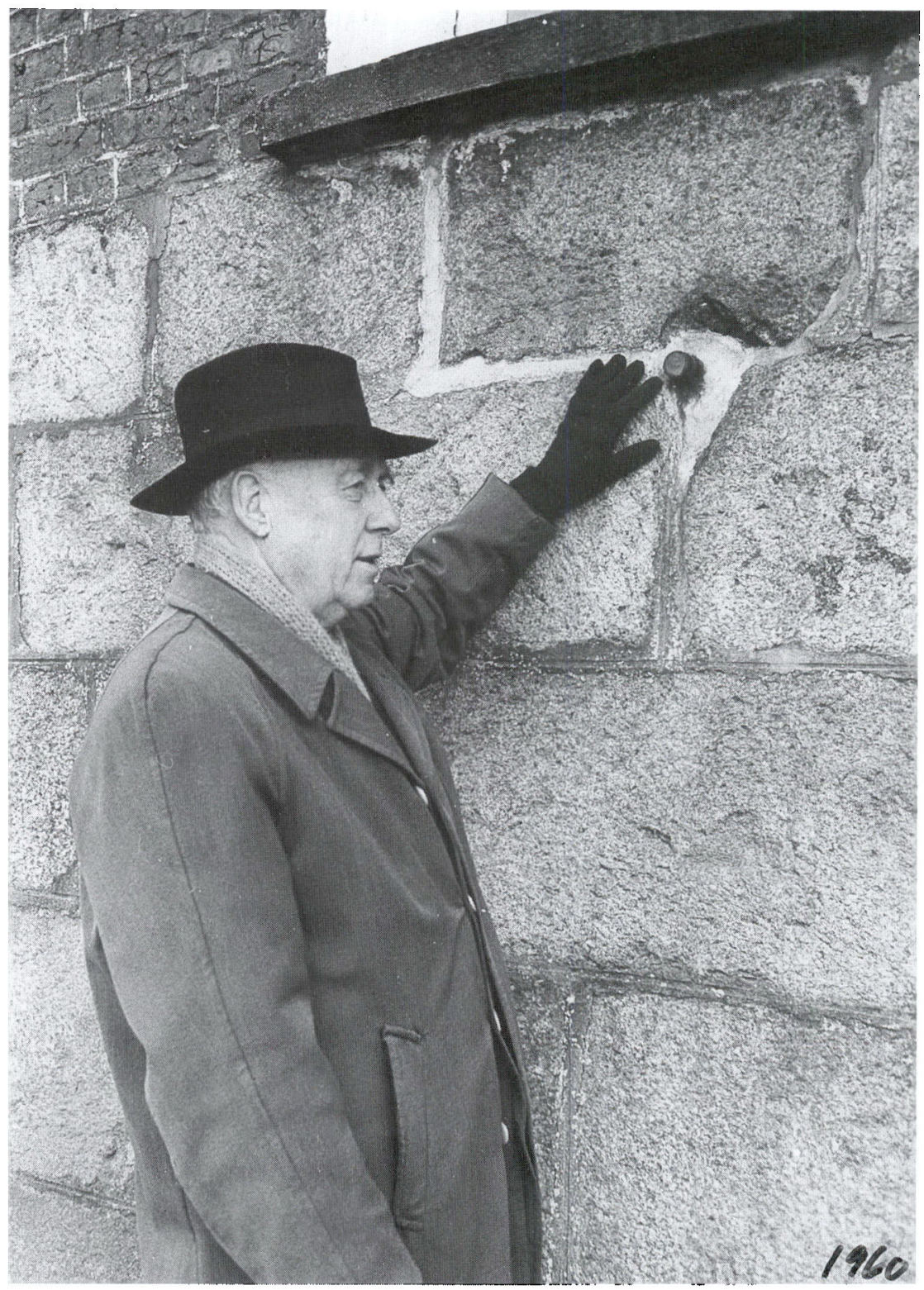

Provst Holdt viser her sporet $i$ Brede kirkes mur efter den tyske granat fra 9. april. Foto ca. $1960 i$ Lokalhistorisk Samling, Bredebro.

lister som vejvisere. Troligt. De skulle allerede aftenen i forvejen have gennemkørt ruten og så underrettet visse hjemmetyske ledere. ${ }^{3}$ 
Cykel- og radioforhandler Max Müller i Bredebro, hvis fader i Visby var blevet arresteret af tyskerne i august 1914, følte sig ikke sikker på stedet efter sine antityske udtalelser i tiden forud, og kørte derfor, før tyskerne rykkede ind $\mathrm{i}$ byen, $\mathrm{i}$ bil med familien nord på til Viborg, hvor konen stammede fra. Men da Hitlers soldater jo også kom til Viborg og ikke var standset ved Kongeåen, kunne han lige så godt tage hjem igen.

Over middag var byen fri for tyske tropper. Og danske så vel som hjemmetyske sogneboere fik tid til at sunde sig over det skete og tænke hver deres tanker og tage hver deres forholdsregler. Radioen og avisen bragte næste dag de udstedte tyske forordninger. Landet var blevet besat af fremmede, »de grønne«, som havde tiltaget sig den øverste magt. Men ellers skulle livet fungere videre i de vante former. Det var en kold aprildag ude. Dens uventede voldsoverfald gav frysefornemmelser i danske sind, men kaldte også på modige og varme hjerter.

\section{Indkvartering og forhor}

Efter besættelsen af Danmark og Norge, hvorved Tyskland fik sin nordflanke fri og sikret, gik det så 10/5 løs mod vest, mod Holland, Belgien og Frankrig, som hurtigt nedkæmpedes. 19/5 kom tyske tropper tilbage fra Nordjylland (28. division fra Breslau) på vej til den franske front. Vi fik et par dages indkvartering i sognet. Bataljonsstaben kom til præstegården. Præsten lå i sengen med lidt feber på grund af en tandrodsbyld (eftersmæk fra kæbeskud ved Moulin 6/6 1915). Snakken gik, at præsten, der jo var tysk officer i 1.verdenskrig, ikke ville hilse på de tyske officerer, som lå i gæsteværelserne. Adjudanten kom da ind og hilste kort. Men nævnte Willms havde også fortalt de nye tyske tropper om præstens »uforsonlige danskhed « og om kirkenøglen til de danske soldater.

Der indfandt sig da 21/5 om aftenen kl. 21 en feldwebel (Wolfram) og en underofficer (dr. Ritter), begge jurister i civil, indkvarterede på »Vældgård«. De kom op i soveværelset og gjorde honnør ved sengen, uden ellers at præsentere sig. De ville gerne have at vide af mig, hvad der var sket 9. april ved kirken. Da jeg havde fortalt dem om begivenhedernes forløb og min deltagelse i dem, begyndte et protokollat, hvor forhørslederen dikterede enkelthederne til kollegaen, der nedskrev, hvilket jeg så til sidst måtte underskrive. - Men dermed var sagen også for mit vedkommende ude af verden. Man havde åbenbart kunnet indse, at det hele beroede på angiveri.

\section{Versailles-dagen}

På Versailles-dagen 28/6 havde adskillige hjemmetyskere flagstænger parat, også vor nabo, dyrlæge B., der stammede fra Hjerpsted og var gift med en 
tidligere feriepige fra Kiel efter 1920. Slægten er i sin tid indvandret til Vestjylland, vel fra Mecklenburg. Der ymtedes om, at Hitler havde bestemt Versaillesdagen fra 1919 til genindlemmelse af Nordslesvig i det tyske rige. Men det blev en skuffelse for »Heim ins Reich«-folkene. Hagekorsflagene, som vel lå i skabet, kom ikke op den dag. Danmark måtte ikke stødes, men skulle helst vindes. ${ }^{4}$

\section{Tysk og dansk arbejde}

Fredag 13/9 blev der i den »gamle«, nu kaldt »tyske kro« i Bredebro stiftet en tysk »Frauenverein«. Fru Jessen, Åspe, blev leder, fru B. talte om »unser Führer«, hvilket påhørtes stående. Købmand J.S. Brodersen, Bredebro, udbragte et »Sieg-Heil« osv. I de påfølgende dage søgte man at tegne medlemmer $\mathrm{i}$ sognet. I Harres var fru Jessen og fru Aabling Matthiesen, Harres, stammende fra Sydslesvig, undervejs, men har næppe fået mange medlemmer. I Abterp var man gået til fru Sturm (født Knudsen), som var blevet meget opbragt over denne henvendelse. Hun var selv af dansk slægt på ejendommen.

Tømrer A. Beyer Jacobsen, Bredebro, som 9. april fòr rundt og søgte at afholde de danske soldater fra at skyde, og en del flere er rejst på arbejde i Tyskland. "Ortsgruppenleiter« er den unge gårdejer Broder Ratenburg, Borg, hvis oldefader var præst i Brede 1845-74. De forskellige hjemmetyske forbund, civile og halvmilitære, har naturligvis deres medlemmer i sognet, men ikke i større tal. Da et tysk militærorkester gav koncert på »Stjernen« i Bredebro mødte kun få tilhørere, så den skuffede dirigent spurgte »Wo ist die Zivilbevölkerung«.

Mandag 16/9 blev »Dansk Samfund« for Brede sogn stiftet i forsamlingshuset. Ca. 500 var til stede, ca. 800 havde allerede indtegnet sig. Formanden for "Dansk Samfund« i den truede firkant, som nu udvidedes til alle Nordslesvigs sogne, gårdejer Hans Andersen, Kongsbjerg, indledede, pastor N.P. Nielsen, Højer, sluttede. Lærer Holger Andresen, Harres, valgtes til formand. En god optakt til samling på den danske modstandsfront ${ }^{5}$ - på tværs af politiske og sociale skel. Alle ville være med, i hvert fald det overvejende flertal af sognets befolkning. Også såkaldte »blakkede« sørgede for at komme på den rigtige side af stregen. Ingen ville flyttes syd på eller engageres i Hitlerkrigen.

Fredag 20/9 talte jeg ved generalforsamlingen i DSK (Dansksindede Sønderjyske Krigsdeltagere fra 1. verdenskrig), formede mine ord ud af tiden og i tro til fremtiden om »mindets stormagt, mandens værnepligt og troens sejr«. Søndag 22/9 bad vi for kongen i kirken. 23/9 var lærer Andresen og jeg til Danske Samfunds tillidsmandsmøde i Tønder. Hans Andersen ledede mødet. Portør Alfred Kristensen, Bylderup Bov (socialdemokrat, landstingsmand) gav en oversigt over situationen, bygget på oplysninger fra et møde på »Folkehjem« i Aabenraa dagen i forvejen: Vinteren tegner meget mørk for Danmark, sagde 
han bl.a. I begyndelsen af det nye år vil vore lagre være opbrugte. Der skal i de enkelte hjem sørges for indkøb af fedtstoffer. De små hjem må støttes $i$ dette beredskab. Clearing-kontoen i Berlin er nu på 300 millioner. Værnemagtskontoen i København er på 250 millioner. ${ }^{6}$ Ved finansårets udgang vil Tyskland have tappet os for værdier og arbejdskraft til et beløb af ca. 1 milliard kr. Det skal nok mærkes på rigets finanser. Man mærker også begyndende stemmekøb fra tysk side. Det vil blive værre til vinter. $-24 / 9$ var styrelsen for Dansk Samfund derefter samlet til rådslagning i præstegården.

Og så kom Christian X's 70-års dag 26/9. Forsamlingshuset var til kongens fødselsdag fyldt som ikke siden afstemningsdagen. Begge sale, scene og forstue var tætpakkede af ca. 600 mennesker. Højskoleforstander Hans Lund, Rødding, talte mandigt og stærkt om tiden efter $1864 \mathrm{og}$ nu efter 9. april. Vi har det gode håb, sagde han, om en lykkelig udgang. Stemningen er vendt i løbet af august og september. Det danske folk har fundet sig selv. Så kan tyskerne og i deres kølvand nazisterne rase, så meget de vil. De er afmægtige mod en enig folkefront. - De gamle sange bruste gennem huset. Naturligvis fik også kongen og flaget og modersmålet deres fuldttonende »Leve«. Den ydre årsag til stemningsomslaget, det nye danske mod og håb, var naturligvis Englands heltekamp og den udeblevne invasion.

Dyrlæge B. sagde mig sin mening på kongens fødselsdag, da vi danske var i feststemning i den flagsmykkede by. Vi mødtes på vejen mellem vore huse, hvor han puslede rundt i surt humør. Han kogte indvendig, mente, jeg hellere burde blive politiker, da jeg stod med et ben $i$ kirken og det andet $i$ det nationale, beskyldte mig for at så splid mellem folk, f.eks. mellem ham og hans hjemsogns præst Petersen, som vel også havde bekendt sin danskhed overfor ham. Han truede med, at afregningens dag ville komme for mig, som skulle have udtalt, at visse statsoverhoveder skulle skydes. (Hvad jeg aldrig havde udtalt) Fru B. viste sig så i garageporten og trak sin mand indenfor.

I oktober fik vi brød- og smørrationering.

Hjemmetyskerne syntes at gå rundt med en lidt dårlig samvittighed. Fru Ratenburg ville - efter eget udsagn - helst undgå at hilse på præsten ved begravelseskaffen i Borg kro. Han må jo dog være meget forbitret på os, havde hun udtalt. (Hun havde under krisen ved Jefsen Christensens mellemkomst også fået ordnet et dansk hypoteklån på ejendommen ${ }^{7}$ ). Vi mødtes alligevel ude $\mathrm{i}$ forstuen efter samværet, hvor jeg gav hende hånden. Det er vist »den sorte bog" over danskerne, man fører, og som ligger hos »sogneføreren«, der afstedkommer den skrantne samvittighed og helst gåen udenom. Dyrlægen, som jo har ret til bilkørsel og kommer ud til mange folk, skal regelmæssigt tage ind til Ratenburgs, men først efter mørkets frembrud. Da kommer der måske dagsnyt $\mathrm{i}$ bogen. 
Hitler og Mussolini mødtes i Brenner 4/10 og i Firenze 28/10 og aftalte den nye krigsskueplads på Balkan. Churchill holdt sine korte, men stærke taler. Hitler talte i München i »Löwenbräu« 8/11 i anledning af kupdagen i 1923, en rasende, hadsk, selvovervurderende opsang. Roosevelt valgtes med stort flertal 5/11. Dermed er krigens videre forløb blevet afgørende bestemt.

På våbenstilstandsdagen 11/11 var jeg nede på kirkegården ved mindestenen for sognets 58 faldne. Ingen blomster eller kranse smykkede den, idet vore "gæster « i øjeblikket har forbudt kransenedlæggelse. Men i aften vil der af DSK blive lagt en krans med rød-hvide bånd ved stenen.

Irene Paulsen, Bredebro, skal være leder af »Hitler-pigerne«, som dog først skal lære at marchere. Gæstgiver P. Andersen, hvis ejendom siges at skulle til tvangsauktion, skal til Esbjerg som tolk. På kroens og maskinhandler Jens Petersens mure er der nu hvert sted 5 nazi-plakater. Smed Eskild Jacobsen, Bredebro, har slebet spade de sidste dage. ${ }^{8}$

15/11 var der Dansk Samfunds aften for Brede by i præstegården med lærer Svane, Borg (socialdemokrat) som indleder om »Arbejderbevægelsen i Danmark «. Der var mødt 50-60, hovedsagelig fra selve byen, men også fra Svanstrup, Storde og Trelborg. Svane læste efter kaffebordet »En flænge« af Zakarias Nielsen, jeg kapitlet »Tågen« af Anker Larsens bog »Sognet, der vokser ind i himlen«. Vi sang af den lille »Dansk Folkesangbog « og øvede en del kanons til megen morskab for deltagerne, hvor også arbejderhjemmene var repræsenterede.

I Sølsted forsamlingshus så jeg 19/11, da jeg talte ved DSK's generalforsamling dér, en duplikeret ordre til alarmsamling i SA-hjemmet ${ }^{9}$ (bomhuset nord for Tønder) 21/11. Alle mand skulle møde. Kun »dødsfald « gyldig undskyldning. 2 ører i straf for hvert overskredet minut af den fastsatte mødetid. »Tag en interesseret med «. - Mødet syntes at have en vis betydning, "hvis vi ikke har overtaget magten forinden«, stod der.

29/11 erklæres Jyllands vestkyst for militært område (ingen handel ved dørene m.m.).

Lærer Svanes næste foredrag 22/11, anden del, hos gårdejer Søren Nissen, Harres, ledende venstremand, vakte stærk kritik på stedet. 28/11 fulgte en meget god »hjemmeaften« på mejeriet hos H. Lorentzen, 29/11 fortsattes i Borg hos gårdejer Ingvart Møller.

Søndag 1/12 blev Esbjerg bombarderet og gasværket ramt. Her i byen arbejder man med oprettelsen af en tysk privatskole. Dyrlæge B. er mellemmand. Hans ældste søn skal i skole til foråret. Han har budt på forskellige huse. Inventaret er ankommet.

I »spadeslaget « i Haderslev mellem nazister og politiet 8/12 deltog her fra sognet den unge gårdejer Niels Petersen, »Vældgård«, og den gamle handelsmand Anders Karstensen. De blev arresterede, men bagefter hjemsendte. 


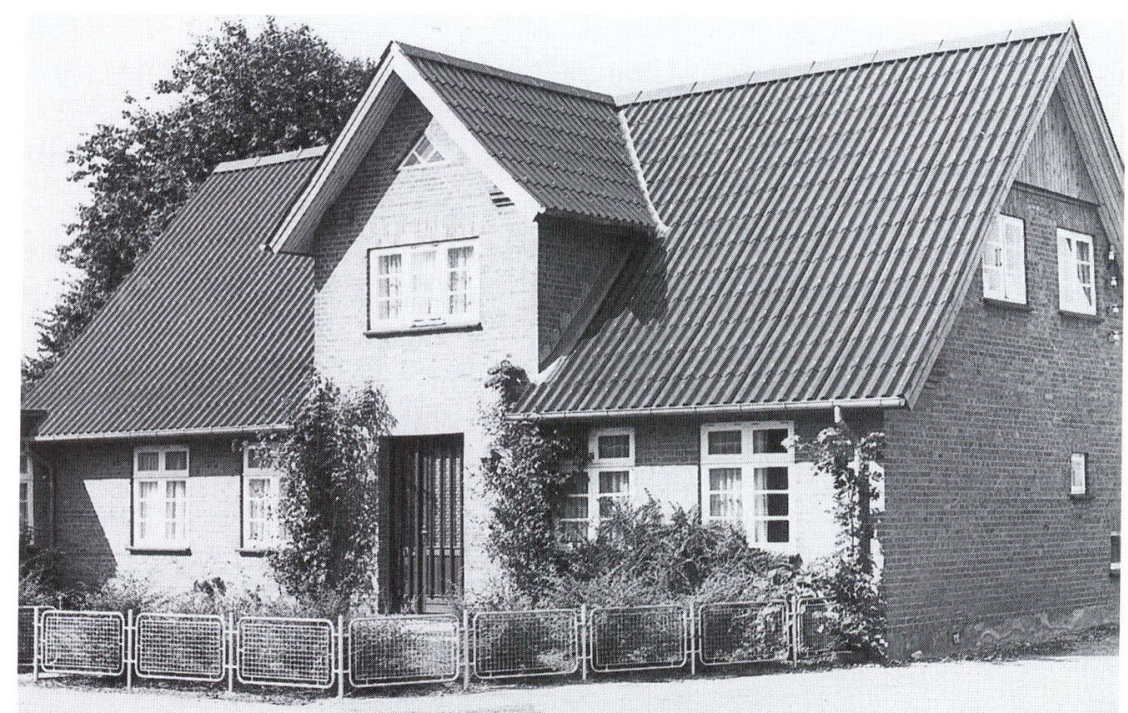

$-$

I denne ejendom Søndergade 10 i Bredebro var der tysk skole under besattelsen. Foto: Lokalhistorisk Samling, Bredebro.

Lørdag 14/12 skal der for første gang være tysk "Gemeindeabend « i den tyske kro. Man har hidtil hver anden onsdag holdt tysk $»$ Frauenschaftsabend«. Borg kro er opgivet som samlingssted. Alt sammen »ild i strå «. »Spadisterne« annoncerede uroligheder til søndag 15/12. De udeblev, men en flok uden spader cyklede om eftermiddagen gennem byen ad Tønder til.

\section{1}

Tysk privatskole

Nytårsaften blev det klart, at den tyske privatskole er en kendsgerning. Man har valgt Willms's Vogelgesang-ejendom, hvor storstuen skal indrettes til klasseværelse. Til morgen er der kørt sand og sten til stedet. Dyrlægen synes at være foregangsmanden. Han farer afsted i sin bil i agitation. Hans praksis er svundet ind, idet mange danske landmænd ikke mere vil benytte ham, men tager udensogns dyrlæger. Søndagen mellem jul og nytår var der tysk juletræsfest i den tyske kro, hvor danskerne ikke mere kommer. Nytårsdag var jeg dér for første gang efter 9. april til begravelseskaffe. Der så så upropert og fattigt ud. Værtsfolkene viste sig kun lige i begyndelsen og forsvandt ret omgående. 
J.S. Brodersen og P. Andersen skal begge have fået Vogelgesang-lån i deres ejendomme. Så er de bundne.

Nytårsdag var der en meget lødig udsendelse i radioen med en stærk kristelig understregning. Professor Hal Koch og forstander Johannes Petersen-Dalum talte som kristne danske. Alt til styrkelse af den danske modstandsfront. ${ }^{10}$

$17 / 1$ blev den tyske privatskole indviet i Bredebro. Høje herrer fra de tyske sammenslutninger var til stede, nemlig dr. Gäde, leder af det tyske gymnasium i Aabenraa, redaktør dr. Harboe Kardel, »Nordschleswigsche Zeitung«, bibliotekar Callesen, skolekonsulent Elholm, gårdejer Jef Blume, Nr. Løgum, som personlig repræsentant for »føreren« Jens Møller, endvidere privatskolelærerne fra Vennemose, Løgumkloster (Jürgensen, alias »Asmus von der Heide«) og Skærbæk (Thaysen). Man samledes i skolen sammen med børnene og deres forældre, 3 fra Bredebro, 5 fra Borg, 5 fra Randerup, 2 fra Ballum, 2 fra Flesborg, 1 fra Sølsted. Lærer er Jes Jessen fra Øsby. Parteigenosse Broder Ratenburg, "den utrættelige forkæmper for en tysk skole i Bredebro«, bød velkommen. Gårdejer Andreas Jensen, Harres, blev udpeget til formand for "Deutscher Schulverein Bredebro«, men var vist ikke til stede. Bagefter var der kaffebord i den tyske kro, hvor P. Andersen sluttede med ordene: „Vi vil danne en blok så hård som stål. Vi står i fast tillid til den tyske skole«. Dyrlæge B. var ikke til stede, vel af hensyn til sin praksis. Skolen fik et hagekorsflag foræret. Medens gæsterne indfandt sig, gik en flok mindre Bredebro-drenge, deriblandt Bent Hersbøll og slagter William Petersens med dannebrog syngende gennem gaderne. En lille dansk demonstration mod den tyske skole pá stedet.

Fra Sudeterlandet er der ankommet en sending kul som "Liebesgaben « til de hjem, som lader sig købe til at sende deres børn i tysk skole. Nogle børn græd, da de skulle bort fra den danske skole og kammeraterne.

I »Nordschleswigsche Zeitung《's rubrik »Unsere Stimme« (Asmus von der Heide) bragtes først i marts et angreb på den danske befolkning i Bredebro, fordi den »saboterede den kulturelle frihed" ved indvielsen af privatskolen.

Kommune- og amtsrådsvalgene 11/3 blev aflyste.

I pinsen afholdtes »Pimpfen-Lager-West « i Bredebro. Ca. 150 drenge fra "Deutsche Jugend Nordschleswig« deltog, vist hovedsageligt fra Tønder, under ledelse af deres lærere. Ankomst lørdag eftermiddag, eksercits til kl. 23 aften og hele pinsedag fra kl. 6 om morgenen, om aftenen fest i kroen, 2. pinsedag hen imod middag afmarch i retning af Løgumkloster, vel til terrænøvelse i plantagen, 3. pinsedag afrejse. »Nordschleswigsche Zeitung « skrev bagefter om det vellykkede stævne i Bredebro, hvor det tyske flag blev vist for første gang. Men samtidig ankedes der over dansk »Belästigung $«^{11}$ og »organiseret flagning med dannebrog «. 
Politisag mod skoleelever

2. pinsedag hen på eftermiddagen indtraf en episode, som kom til at berøre præstehjemmet: Vore to tvillinger, Signe og Grethe, 15 år, der går i Skærbæk realskole og havde været til privat eksamensforberedelse hos deres lærer, var sammen med deres klassefælle Knud Hersbøll, cyklende på vej hjem. Nord for Svanstrup mødte de en lokal nazist og hans kone fra Skærbæk og en tysk underofficer. De var på vej hjem efter deltagelse i Hitler-Jugend festen i Bredebro, hvor forresten også den tyske kaptajn i Skærbæk lod sig se og hylde. Da børnene var kommet lidt forbi de tre, tillod Knud og Signe sig at sige "pøj«, hvorpå de to civile gjorde omkring og overfusede de benovede børn, spyttede på vejen og brugte ukvemsord, medens de forlangte navnene opgivet. Børnene kom skræmte hjem.

Nogle dage senere kom politibetjent Frandsen, Bredebro, med en klage fra den tyske underofficer for »fornærmelse mod den tyske værnemagt«. Børnene giorde gældende, at det ikke var soldaten, men nazisten, der fremkaldte deres ubehagsytring. Politimesteren i Tønder, Martensen-Larsen, kom i samme ærinde og bad om Signes og Knuds underskrift på en »uforbeholden undskyldning for fornærmelig adfærd overfor den tyske værnemagt«. Dermed skulle sagen så være bilagt i mindelighed. Politiet stod svagt i øjeblikket, ytrede politimesteren, idet Gestapo helst ville til. Justitsministeren forlangtes afsat på grund af tiltagende småoptrin overfor »gæsterne« $i$ landet.

\section{Danske og tyske fester}

Valdemarsdagens fest 15/6 fejredes i Frederik Madsens lade, da offentlige møder var forbudt. Der var pyntet med flag og guirlander. Musikken var anbragt på loftet i en »flagstue«. Jeg talte om »rettens majestæt«, et foredrag, jeg også har holdt andre steder. Efter kaffebordet var der oplæsning ved sparekassebestyrer Asmus Lorentzen og førstelærer H. Henriksen, Bredebro. Småtaler blev holdt af gårdmændene Claus Clausen, Harres, og Jens Lund Petersen, Borg, o.a. Stemningen var god, og festens særpræg vil blive husket af deltagerne.

22/6 kom angrebet på Rusland. V-tegnet driller tyskerne. Jeg fandt det malet på asfalten ved »Vældgård« og tegnet $\mathrm{i}$ en grusbunke ved Harres.

Søndag 13/7 var der tysk frimenighedsgudstjeneste ved pastor Raun, Løgumkloster, det halve deltagerantal fra sidste gang. Dyrskueaftenen, 26/7, var der stor ballade i kroen, som politiet lukkede. Dyrlæge B. ligger i spektakel med sognerådet.

27/8 rejste Niels Petersen, "Vældgård«, fra kone og børn til Tyskland. Han har ikke længere kunnet undslå sig, men måttet aktivt gå med i kampen mod »Bolschevismen«, efter at et par landbrugsmedhjælpere fra sognet i forvejen 
var sendt af sted og nu skrev efter deres lokale fører. Også lærer Jørgen Paulsen, Sdr. Vollum, og Wilms's søn er sydpå. Der bygges lyttetårne for flyvarsling på Vognshøj og ved Sølsted. Ved Højer faldt natten til 20/8 en engelsk flyvemaskine ned. De tre omkomne flyvere blev begravet i Tønder.

2/9 åbnedes en tysk privatskole i Randerup, som overtog 13 børn fra Bredebro-skolen, hvor der nu er 27 tilbage. Natten mellem 3-4/9 var en tank-afværge-patrulje på øvelse i byen.

Utilfredsheden med dyrlæge B.'s virksomhed førte til, at der nedsatte sig en ny, dansk dyrlæge i Bredebro, Westermann fra Esbjerg. Han fik foreløbig lejlighed hos kirketjener Jensen og begyndte sin praksis i den sidste september-uge. Det førte til rådslagning hos dyrlæge B. 25/9 med lærer Jessen, skoleforstanderen Andreas Jensen og montør Nicolaisen, medens ophidselsen fik udløb i sønnens råb på gaden udenfor præstegården: »I forbandede danskere«, ekkoet fra hjemmet.

På kongens fødselsdag 26/9 talte højskoleforstander C.P.O. Christiansen, Frederiksborg, for en stopfyldt sal på hotellet, arrangeret af Dansk Samfund.

Søndag 3/10 var der tysk sportsfest i Bredebro. Hagekorset var for første gang hejst på sportspladsen ved åen. Samtidig var der tysk gudstjeneste med ca. 30 deltagere. Efter denne var der altergang, hvor dyrlægens og fru Ratenburg gik til alters.

Fra november er de danske hjemmeaftener begyndt igen med god tilslutning. Hitlers hære standsedes foran Leningrad og Rostov i begyndelsen af december. Hitler og det tyske folk er blevet nervøse. De har nu også erklæret Amerika krig. Japan går til angreb i østen.

Ved Dansk Samfunds generalforsamling på hotellet den 12/12 vistes 7 farvestrålende nationale tableauer, komponerede og fremførte af pastorinde K. R. Holdt.

\section{2}

Hitlers standsede offensiv i Rusland kalder også på hjemmetysk frontindsats mod »bolschevismen«. 18/2 offentliggør »føreren« Jens Møller, Gråsten, et opråb, dateret 10. februar, til årgangene $1902-23$ om at melde sig frivilligt til fronttjeneste. Fra Brede sogn blev det vist kun Jens Ratenburg, partilederens yngre bror, som meldte sig, eller blev indmeldt i stedet for broderen.

Flyvervirksomheden tiltager. Ved Jejsing styrtede en amerikansk bomber ned med 6 mand og en tysk jager med 2 mand. Kirkekampen i Norge ${ }^{12}$ følger vi med spændt opmærksomhed.

$15 / 3$ holdtes for første gang tysk konfirmation i Brede kirke ved pastor 


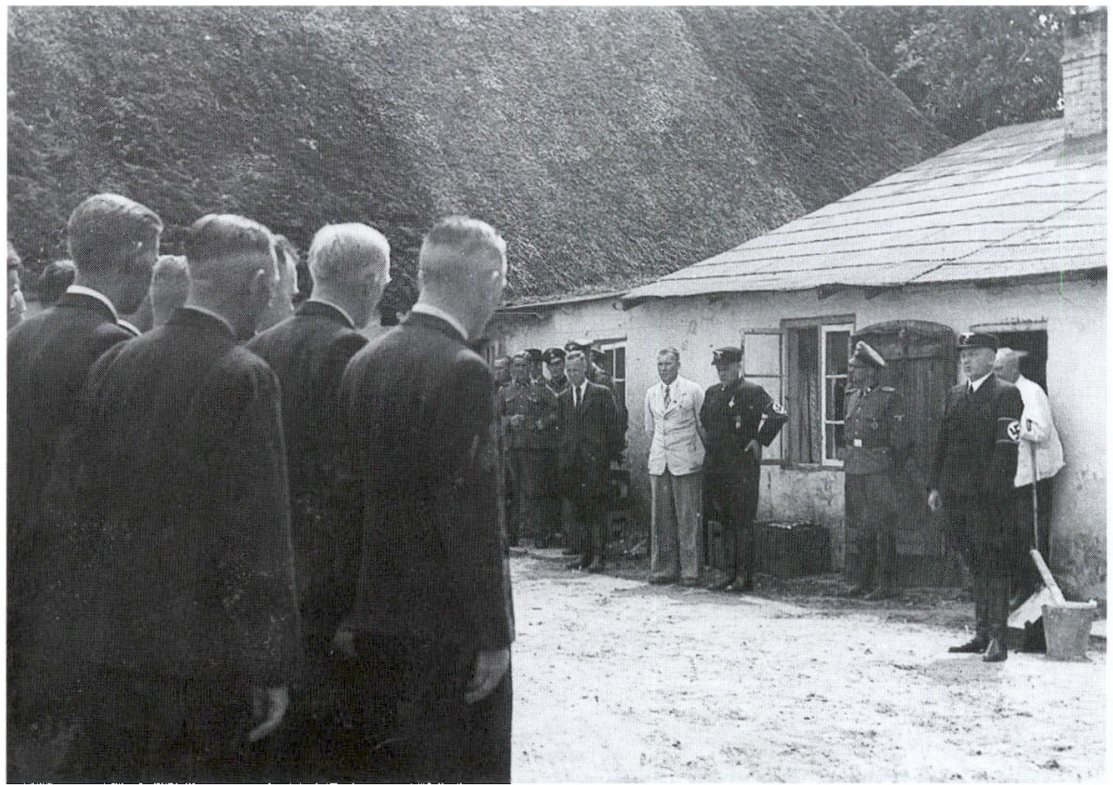

Inden afrejsen til tysk fronttjeneste modtes de "frivillige" $i$ Tinglev. Her tager "Landesführer der SK Larsen " afsked med de frivillige 6.juli 1942. Foto Gimm i Institut for sonderjysk Lokalhistorie.

Raun. Han har forøvrigt i sidste nummer af det tyske »Gemeindeblatt« skrevet en stærk og god prædiken om $"$ Das Kreuz als Waffe«.

$25 / 3$ var der tysk session i Løgumkloster, hvor der blev udtaget tre fra Borg. Det ser ud til, at en tidligere tysk »underskrift« nu binder adskillige til militærtjeneste, skønt de nødig vil selv. Der er udsendt en personlig opfordring til de pågældende. Andreas Jensen og Broder Brodersen, Brede, gav hinanden hånd på, at de ikke ville melde sig. Også andre unge i Borg, Beyer-sønnerne, undslog sig.

\section{Eksamen i den tyske skole}

Skolekommissionen var indbudt til eksamen i den tyske privatskole $30 / 3$ om eftermiddagen. Vi mødte tre mand, som overværede forestillingen fra først til sidst med nazi-ceremonier til begyndelsen og afslutningen. Læreren viste forholdsvis gode resultater med børnene. Da der skulle begyndes på andet vers af indledningssalmen "Vor Gud han er så fast en borg", som jo lyder "Slet intet er vor egen magt, let kan os fjenden fælde« standsede han børnene og sagde: 3 . vers »Og myldred djævle frem på jord og os opsluge ville«. Vi hørte en time $i$ tysk og regning, derefter $i$ dansk, historie og geografi. En lang omgang, men børnene var villige og ihærdige - med mange små sprogmor- 
somheder. De større børn, der havde gåt i dansk skole, kunne bedst det danske sprog, deres modersmål. Religionen var man endnu ikke nået til, da man havde måttet slide med det tyske sprog, forklarede læreren. Landkortet måtte vi ikke få at se. Det har vel haft »forbudte« eller »falske grænser« optrukket. På skolepladsen forsøgte børnene at tale tysk.

$1 / 5$ kom en engelsk nedskudt flyver ind til Anders Bennedsen i Harres, men han kunne ikke skjules og måtte i fangenskab. Statsminister Stauning døde $3 / 5$.

Den nye tyske offensiv på østfronten begyndte 30/6.

Jernbanebeskydningen fra allierede flyvere mærkes nu også på vore kanter. 11/7 faldt en bombe i Jernbanegade i Tønder, tiltænkt stationen, 5 døde. Godstoget nordpå blev ramt i lokomotivet nord for Døstrup, lokomotivføreren død, fyrbøderen hårdt kvæstet ${ }^{13}$. Ved Abild faldt en tysk maskine ned.

Dansk militær skal nu rømme Jylland inden 15/11. Tyskerne regerer. Dr. Best er kommet til Danmark og E. Scavenius skal være statsminister.

Den første vielse på tysk i Brede kirke fandt sted 30/10, da Tinne Brodersen viedes af pastor Raun til en Krag fra Skovby på Løjtland. Isolationen er følelig. 13/11 rejste de danske soldater fra Tønder til Assens. Obersten talte fortrøstningsfuldt: „Vi kommer snart igen«.

14/11 talte Erik Appel og Jefsen Christensen ved et fortroligt tillidsmandsmøde for Venstre på hotellet om den nye regeringsdannelse. "Det gik bedre end ventet $\lll$, sagde de. »Scavenius er mere bundet i dag end før

\section{3}

I anledning af den tyske privatskoles ansøgning om statstilskud overværede jeg 7/1 om formiddagen undervisningen i skolen. Læreren Jes Lauesen Jessen er født 22/4 1911 i Øsby, bestod 1. prøve ved »Hochschule für Lehrerbildung« i Kiel 16/ 9 1936, 2. prøve i Riesbrick ved Flensborg januar 1941, ansat i Bredebro 16/1 1941. Hans historiehåndbog, Gehl: Deutsche Geschichte in Stichworten, 1939, som lå på katederet, indeholder bl.a. følgende passager: 1789: „Entnordung Frankreichs«. - Danmark: »Deutscher Kulturboden«. - 1864: »Entdeutschung Schleswig-Holsteins verhindert«. - 1920: Enbloc-afstemning for at få de tyske amter i Aabenraa og Tønder med til Danmark. Stemmeprocenterne angives ikke. Kommunevis afstemning i 2. zone for at få danske distrikter med til Danmark, men det forhindres med $80 \%$ tyske stemmer. Afstemning i 3. zone blev derfor opgivet. - 1918: Den tyske hær ubesejret. Dolkestød bagfra. Manglende ammunition efter strejken i januar 1918. - 1939: Polen ville erobre tyske provinser, »darum Gegenstoß notwendig«. - Stærk antisemitisme og antikommunisme. 


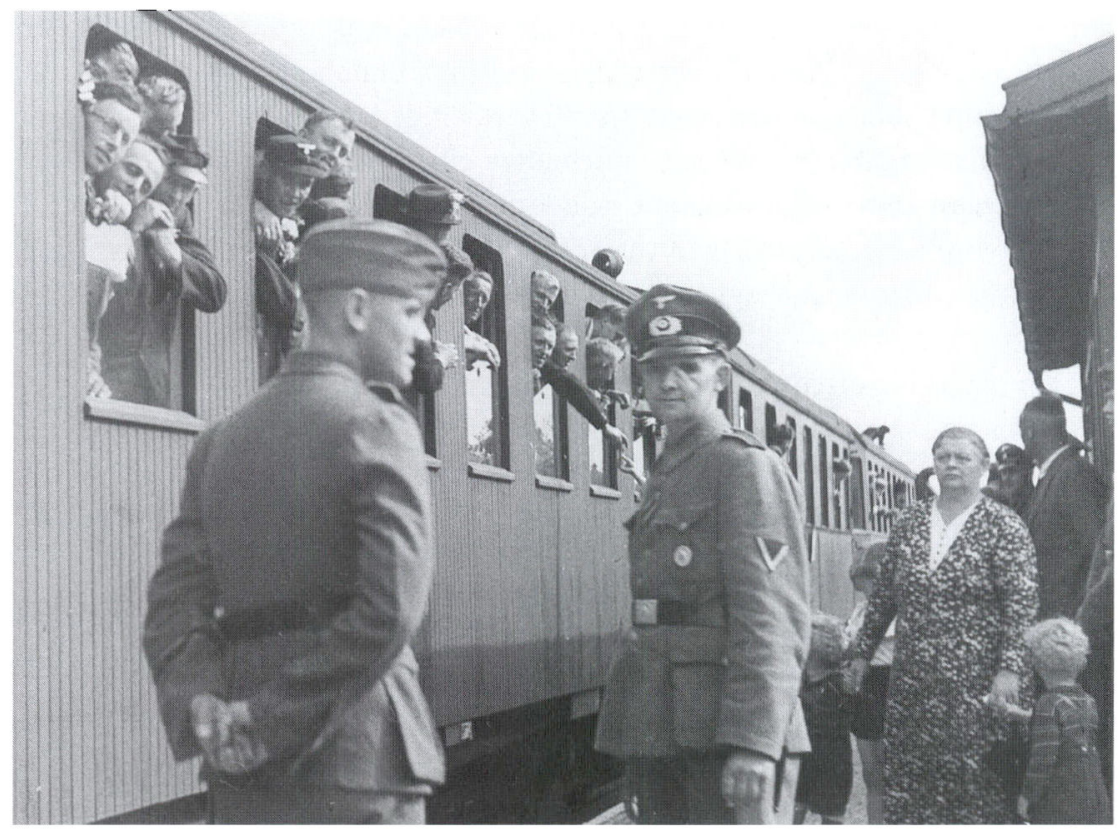

Hjemmetyske frivillige på vej til fronten fotograferet ved afrejsen fra Tinglev 6.juli 1942. Foto Gimm i Institut for sonderjysk lokalhistorie.

31/1 kapitulerede generalfeltmarskal Paulus foran Stalingrad. Det gav et vældigt chock i det tyske folk.

\section{Prcestesolidaritet}

Provst Schülein, Løgumkloster, nægter at medvirke ved mindehøjtidelighed i kirken for en falden frikorpsmand fra Ellum, hans tidligere konfirmand, der mod hjemmets vilje er taget til østfronten. Pastor Raun, som så skulle have tjenesten, anmodede på Bredebro station, hvor vi tilfældigt mødtes, mig om at overtage den, hvad jeg dog afslog som mig uvedkommende. Han sagde i sin mindetale bl.a.: Hvis denne unge mand havde overholdt det 4. bud, havde han i dag ikke ligget i Ruslands jord. Det var modigt sagt.

Provst Schülein blev i den anledning stærkt angrebet i nazi-partiorganet »Fædrelandet« og $\mathrm{i}$ »Zeitung«, idet han til den faldnes pårørende, en farbror, skulle have sagt, at man jo ikke vidste, om han wvar skudt forfra eller bagfra«. Menighedsrådet og præsterne i Tønder Provsti sluttede op bag provsten. Pastor Helms, Mjolden, og jeg overbragte ham 19/2 en solidaritetsadresse. Men Jens Møller lader på partidagen, søndag 14/2 i Haderslev, vedtage en resolu- 
tion, hvori provst Schülein, pastor Warncke, Ullerup og lektor Rosent, Aabenraa, ved henvendelse til statsministeriet kræves fjernet fra grænselandet. Det førte til en provsteretssag, hvorefter provsten fik en ministeriel reprimande for de fremsatte udtalelser.

Præsternes erklæring, som indsendtes til kirkeministeriet, havde følgende ordlyd: "I anledning af det angreb, som fra det tyske mindretals side i disse dage er blevet rettet mod provst Schülein, Løgumkloster, erklærer vi vor solidaritet med vor provst. Vi kender provsten som en mand, der i sit over 20årige virke som præst i grænselandet altid har bestræbt sig på en korrekt og frisindet optræden overfor mindretallet. Vi tilbageviser derfor bestemt kravet om provstens fjernelse fra grænselandet som i enhver henseende ubeføjet«. Tiltrådt af alle præster i provstiet.

16/2 væltede dyrlæge B. i Borg med sin bil. Sønnen knækkede kravebenet. Ingen syntes at ville hjælpe ham. Man stod med hænderne $i$ lommen.

Der går stadig rygter om lærer Jessens afrejse til fronten. Den unge Jens Ratenburg ligger i Karkow med forfrysninger i den ene fod. Han døde siden, den eneste fra Brede sogn. SS-Totenkopf-divisionen, hvortil hjemmetyskerne hører, har været med i slaget ved Karkow.

Der er nu indrettet patruljevagter ved jernbaner og fabrikker i landet. Der finder ustandseligt store overflyvninger sted med bombning af tyske byer som mål.

Udenrigsministeren har gennem kirkeministeriet pålagt danske præster at afholde sig fra at omtale den norske kirkekamp. Præsterne i Tønder provsti protesterer officielt i skrivelse til ministeriet mod dette pålæg og udtaler at de »kun føler sig forpligtede overfor sandhed og ret«. Skolebørnene samlede midler til »Norgeshjælpen« og til Sydslesvig.

$23 / 3$ var der rigsdagsvalg. Tyskerne deltog ikke. I stedet for har de fået et kontor under statsministeriet, som ledes af Rudolph Stehr, hvis far en kort overgang var mejeribestyrer i Bredebro, siden vært på amtsbanegården i Skærbæk. Stort dansk stemmetal. De danske nazister er på retur.

26/3 meldes om et bundt brandbomber på Harres mark, der brændte ud. Ved Lovrup faldt også et bundt, som ikke kom i brand. Maskinen gik ned ved Obbekær.

Onsdag 7/4 mødte 16 præster fra provstiet, som havde protesteret mod forbudet at omtale den norske kirkekamp, efter tilsigelse på missionshotellet $\mathrm{i}$ Tønder. Vi fik en reprimande fra kirkeministeriet, overbragt af stiftsprovst Riisgaard på biskoppens vegne. Vi truedes efter straffeloven med indtil 2 års fængsel, hvis vi ikke rettede os efter ministeriets henstilling. En ynkelig forestilling og en svag holdning fra kirkemyndighedernes side.

$8 / 5$ forlyder det, at mindretallets ældre årgange, som unddrog sig fronttjene- 
sten, skal få lov til at gå vagttjeneste syd for statsgrænsen, for derved at frigøre tyske vagttropper. ${ }^{14}$

19/5 dagangreb på Kiel og Flensborg. En dansk børnehave i Nystaden ramtes, 15 børn og 2 lærerinder døde, dertil på Duborg fru redaktør Tage Jessen i sin lejlighed.

1/6 sabotage på 6 lokomotiver i Tønder remise om natten. ${ }^{15}$ Der er nu tysk jernbanevagt ved broerne her i sognet.

Torsdag 17/6 lidt før kl. 6 om morgenen stak der ild op i den tyske skole i Bredebro. Den nedbrændte totalt. Alt indbo i skolen og i de tre lejligheder gik op i luer. Årsagen er formodentlig en utæthed i skorstenen - efter opfyring med aviser ved en fest om aftenen til ud på natten, selvom der også nævntes sabotage og provokation. Skolen er nu provisorisk indrettet i den tyske kros pakhus, hvor der også skal indrettes rekreations-hjem for udbombede børn fra Hamborg. 30/6 ankom ca. 30 underernærede drenge med deres lærer til lejren. Hamborg bombarderedes dag og nat i slutningen af juli.

20/8 meldes om generalstrejker i Esbjerg og Odense. Der går ustandseligt troppetransporter syd på. Rigsdagen er indkaldt. 21/8 statsråd på Sorgenfri slot, hvori kongen bifalder udsendelsen af et nyt opråb til det danske folk om at »bevare ro og orden«, hvis folkestyret ikke skal gå tabt. Ingen må tage sig selv til rette, som det er sket $\mathrm{i}$ stigende grad i den senere tid med sabotager og strejker.

\section{9. august}

Søndag morgen $29 / 8$ indførtes ved bekendtgørelse i radioen militær undtagelsestilstand i hele Danmark. Regeringen er trådt tilbage. Jernbaner og alle offentlige institutioner kontrolleres af tysk militær, også i Bredebro. Gudstjenesten afholdes som normalt, men alle andre sammenkomster er forbudt. Kun absolut nødvendige rejser tillades. Tyskerne på stedet har været samlet hele formiddagen til rådslagning. Der regnes med, at deres organer skal overtage magten. Rygtet om provst Schüleins arrestation om natten (kl. 4.15) viste sig at være sandt. Han førtes med andre arresterede til kasernen i Tønder og derfra til Fredericia. 11 fremtrædende danske fra Sønderjylland var internerede i 12 dage og løslodes så, man siger efter henstilling fra fornuftige hjemmetyskere, deriblandt pastor F. Prahl, Haderslev, og C. Beuck, Aabenraa, tidligere Tønder. Om eftermiddagen cyklede fru Holdt og seminarieelev Johannes Holdt til Løgumkloster for at opsøge provstinde Schülein. K1. 15.10 opklæber de tyske soldater i lastbil plakater med proklamationen på mure i Bredebro. I Tønder varetager $\mathrm{SA}^{16}$ kontrollen ved byens indgange.

30/8 var jeg på cykel i Døstrup, Mjolden og Abterp. 31/8 cyklede jeg til Tønder for at se på sagerne, var på politikontoret, det tyske kontor i Jernbanegade, hos pastor Magle og fru Eskildsen. Bispekontoret vidste denne tirsdag 
intet om arrestationen, da vi ringede op fra Tønder. Der var mange hjemmetyske patruljer med armbind "Deutsche Wehrmacht « på gaderne, ${ }^{17}$ men ingen visitation undtagen ved banegården.

Samme aften kl. 23 blev tømrersvend Bendix Madsen, Bredebro, vækket i sit hjem og ført som arrestant til Skærbæk af 4 tyske soldater med en lokal mand som tolk. Han skulle have sagt, at nu skulle den tyske skole i kroen også svides af, hvad ikke passede. Om morgenen hjemsendtes han med toget. Slagtersvend Heseler Petersen skulle også have været arresteret, men var ikke hjemme. Han skulle have revet en militærplakat ned, hvad heller ikke passede. Den var regnet ned og forsvundet i nattens løb. Kongen skal have fået en hjerneblødning og være indlagt på Diakonissestiftelsen.

Søndag 5/9 mindedes ved gudstjenesten i kirken vore 23 faldne fra 29 . august $^{18}$ med verset: Guds fred med vore døde. Vi bad for deres efterladte og for de fængslede og deres pårørende. Under bekendtgørelserne opfordrede jeg til at medvirke til besindighed og medmenneskelighed og til at modvirke udæskning og angiveri, hvilket ville tjene alle parter bedst nu og i fremtiden.

\section{Sabotage og prestemodstand}

10/9 blev alle sale beslaglagte til tysk militær. Ca. 300 mand skulle komme om ca. 3 uger.

Lørdag 11/9 vendte gidslerne hjem fra Fredericia. Det nævntes 12/9 i kirken. 13/9 var Magle og jeg i Ribe til en drøftelse med biskop Scharling. Vi fik gode tilsagn: 1. Situationen er betydelig ændret siden sommeren 1942. 2. Velvillig overfor præsternes budtjeneste. 3. Kongens garanti afgørende. 4. En ikke-ønsket minister måtte stå og falde med sine gerninger. 5. Vanskeligt at give direktiver på forhånd, men hurtig besked i den givne situation. 6. Samlet optræden af betydning. 7. Hensynet til tyske folkekirkepræster må huskes. 8. Provst Schüleins tilbageholdenhed bør også respekteres. 9. Et møde med præsterne planlagt. 10. Synspunktet: blive i embedet så længe som muligt godkendt. 11. Meddelelser fra tid til anden, når noget vigtigt foreligger. ${ }^{19}$

Søndag 26/9. Sabotage i nat på jernbanen ved Døstrup og Visby. ${ }^{20}$ Kongens fødselsdag mindedes i kirken. Hans valgsprog »Min Gud, mit land, min ære« indflettedes i prædikenen. Efter den apostolske velsignelse fra prædikestolen sang vi stående "Kongernes Konge«. Kirken var pyntet i røde og hvide farver. Ca. 300 i kirke.

$2 / 10$ bekendtgjorde tyskerne, at de har »udskilt jøderne af det danske folkelegeme«, altså jødeforfølgelse også i Danmark.

Søndag $3 / 10$ blev biskoppernes fælles hyrdebrev mod jødeforfølgelsen, ${ }^{21} \mathrm{der}$ var fremskaffet og rundbragtes ved bud om lørdagen til præsterne, oplæst $i$ kirken. 
4/10 rejses tømmeret på den nybyggede tyske privatskole. Tysk militær indlægger sin egen telefon i Bredebro.

Mærkeligt nok kunne der søndag 17/10 afholdes et kirkeligt møde i Tønder om eftermiddagen på »Tønderhus « med taler af førstelærer Christensen, Burkal, forstander Terkelsen, Danebod højskole på Als, om Harald Kiddes »Helten«. Derefter gudstjeneste i kirken ved Magle, efter tebord om aftenen tale af domæneforpagter Erik Appel, der søgte at »finde melodien igen« efter 29/8. N. P. Nielsen afslutning.

Alle, der kommer fra København, er rystede over jødeforfølgelserne. Oprørende ting er skete. I Bredevad, Højst og Rabsted sprængtes transformatortårnene.

22/10 var der møde med biskop Scharling i Tønder danske præstegård. Han gik ud fra det bibelord, som også biskop Ammundsen brugte i sin tid: Gud har ikke givet os fejgheds, men kærligheds, krafts og sindigheds ånd. - Der er forskel på dansk og norsk mentalitet, sagde biskoppen videre. Der forefindes en lidt farlig aktiv dansk præstementalitet. Derefter referat fra bispemødet $\mathrm{i}$ København 15/10. Biskoppen synes at være svag og for passiv, jeg følger i de mere handlende biskoppers fodspor.

29/10 var Helms ${ }^{22}$ og jeg i Skærbæk præstegård for at give pastor Hansen en lille formaning $\mathrm{i}$ anledning af, at han kun havde læst biskoppernes jødehyrdebrev $i$ uddrag og ligeledes havde vist mangel på holdning ved en mindegudstjeneste, hvor tysk militær var til stede og et hagekors var hængt over talerpulten. Det burde have været fjernet i forvejen fra kirken, når en dansk præst fungerer. ${ }^{23}$

Der har igen været tyske indkvarteringsofficerer i byen, som bebudede 420 elitetropper mellem 6-9/11, men de er ligesom de tidligere anmeldte ikke kommet.

12/11 kl. 19.10 meldes hele Danmark at være i alarmtilstand, hvad der så er i gære. 13/11, formiddag, glinsede i solen over 100 amerikanske bombere i vest-østlig retning nord for os.

15/11 fortroligt illegalt møde i Tønder danske præstegård med pastor N. J. Rald, Frederiksberg. Der bygges nu tysk flyveplads ved Skrydstrup. Von Hanneken har taget hovedkvarter i Silkeborg. Natten mellem 17-18/11 skal han have været til konference med generalstabsofficerer syd fra på »Tønderhus«. Læge Dahl, Tønder, blev samme nat arresteret og ført til Esbjerg.

19/11 journalist Bernsen, Tønder, med flere arresterede ved Gestapo-manden Jessen Michelsen fra. Tønder. 21/11 bøn for arrestanterne i kirken. 23/11 tysk vagt ved broerne i sognet. 24/11 præstekonvent i Brede præstegård. Drøftelse af situationen. Indgået brev fra biskop Scharling bringes til kendskab. 30/ 11 sabotager ved begge indkørsler til stationen i nat, igen om aftenen. 


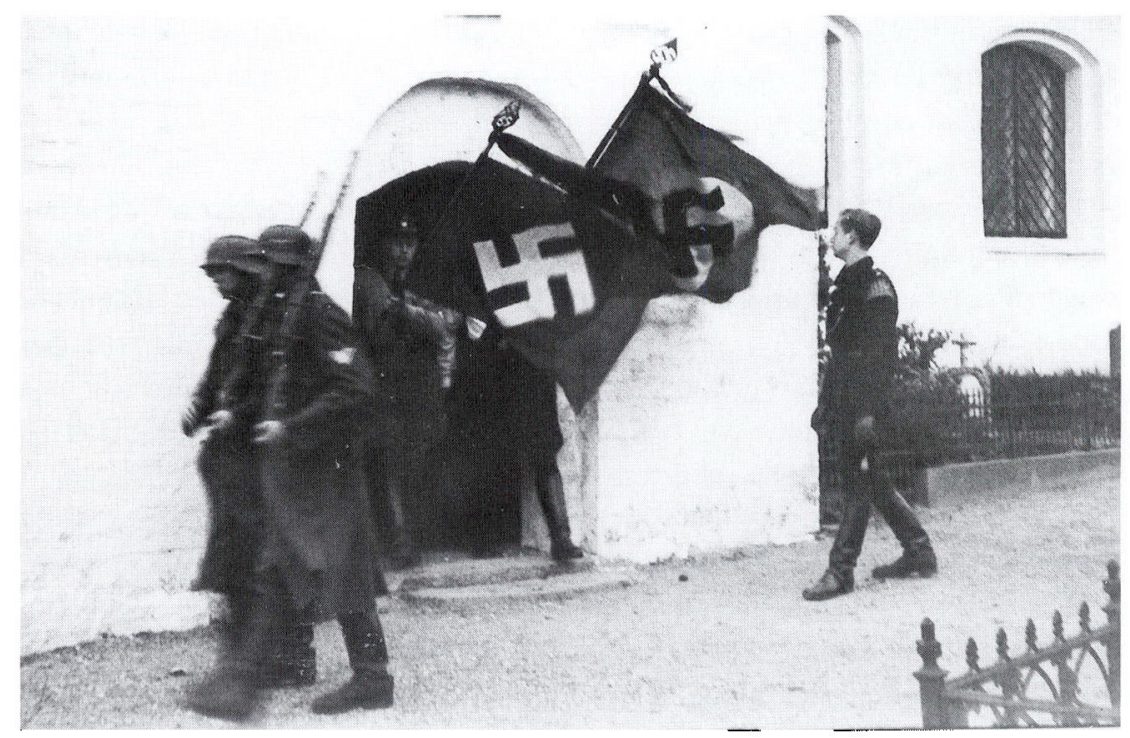

Under besattelsen blev Hagekorsflaget enkelte gange set ved tyske mindegudstjenester $i$ kirkerne. Her bares to faner ud fra Rinkenas kirke $i$ anledning af mindegudstjeneste for G. Horstmann i 1943. Foto Gimm i Institut for sonderjysk lokalhistorie.

10/12 var jeg i Ribe hos biskop Scharling i anledning af sabotørhenrettelserne og det forestående illegale præstemøde i Århus Bispegård hos biskop Hoffmeyer $16 / 12$.

13/12 lektor Rosenkjær arresteret i sin have. Desuden forpagter Mathiesen Hansen, »Hestholm«, ingeniør Bøge eftersøgt. 21/12. Tyske soldater opkøber levende svin hos bønderne om natten.

22/12. Kvartermagere i byen. En vagtmester fra Esbjerg kom på egen hånd til præstegården. Jeg henviste til den påbudte melleminstans, sognefogeden, som burde ledsage ham. Tyskeren optrådte efterhånden meget ophidset og truede med min arrestation, men gik så til sognefogeden. Dagen efter gav han denne en undskyldning for sin uberettigede optræden og rejste tilbage til Esbjerg.

\section{4}

Sabotager og arrestationer tiltager

4/1 blev Kaj Munk myrdet af Gestapo i Hørbylunde bakker vest for Silkeborg. Dette fejge snigmord på vor store dramatiker og modige præst gjorde et over- 
vældende indtryk på os alle. Søndag $9 / 1$ holdt vi mindegudstjeneste for ham i kirken. Efter en kort prædiken læste jeg hans ord ved sin mors båre og hans digt »Påske«, derefter den erklæring, præsterne er blevet enige om, med bøn for de efterladte - og morderne.

$7 / 1$ overværede jeg pligtskyldigt undervisningen i den tyske skole i det interimistiske lokale i den tyske kro. I forstuen hang antisemitiske illustrationer på væggen: "Juda's meriter — - "Morgenthau«, den amerikanske finansminister, jøde - »Chr.Portal«, russisk kommissær, jøde - »Alles Leid und alle Not kommt von den Juden« m.m. Der begyndtes med »Heil Hitler«, derefter kort bøn. I religion det samme stof som sidste år: Juleberetningerne indtil »De vise af Østerland«. Et par bud med forklaringer, trosartiklerne med forklaring til den første. Alt på remse. Ingen salmer. Fattigt. Derefter dansk: ingen virkelig undervisning, åbenbart kun for tilsynets skyld. En historie: »Den lille Kadi i Bagdad« læstes og genfortaltes. Mærkeligt indhold: Tyveri, falsk ed, hængning. Så tysk, hvor der kom fart over opvisningen. Tillært stof med mange sprogbommerter, særlig i de større børns mund. I stilebøgerne fandtes en fristil: "Die Soldaten kommen«, den genspejlede lærerens hadske undervisning forud. Feks.: »Wir freuen uns, dass die Soldaten kommen. Die Dänen ärgern sich, können nicht mehr ins Kino und Versammlungshaus. Die Bahnbeamten schimpfen über jeden Militärzug, der nach Norden fährt. Die Soldaten bleiben vorläufig fern. Aber jetzt werden sie sicher bald kommen«. Historie: Prøjsens opkomst 1411 indtil Frederik den Store. (Ak ja, sådan var det også, da jeg gik i tysk skole, hvor vi begyndte med Albrecht der Bär 1134). Videre: Det menneskelige legeme: kredsløbet, ernæringen. - Geografi: Hjemstavnslære, Schleswig-Holstein til Kongeåen. En del af de mest udæskende data faldt under bordet. Men vi er altså her på stedet ikke i Danmark. »Nach Dänemark verzogen « stod der i forsømmelseslisten ved en elevs navn, der var flyttet til Nordjylland. Grænsen mod nord er: »Jütland « osv. Utåleligt i normale tider, men i dag må vi lade det passere upåtalt. "Heil Hitler« til afslutning. På væggen hang et hidtil ikke set billede af Hitler, hvem jeg på afstand slet ikke kunne genkende. Han syntes at være en olding. Med læreren talte vi sønderjysk. Alt gik militærisk til.

De danske illegale blade, som nu kom regelmæssigt med posten, uddeltes. "Frit Danmark« af præsten, »De frie Danske« af hans bror, seminarieelev i Tønder.

29/1. Sidste nat var den uroligste vi hidtil har haft. Fra kl. 1-3 var der ustandselig overflyvning. I Galleby brændte en mindre ejendom, på »Trøjborg« kornladen. Målet var Berlin.

7-8/2 var Magle og jeg til illegalt præstemøde i Dalum ved Odense, hvor også Harald Sandbæk ${ }^{24}$ var til stede - med revolver og en bunke store pengesedler $\mathrm{i}$ 


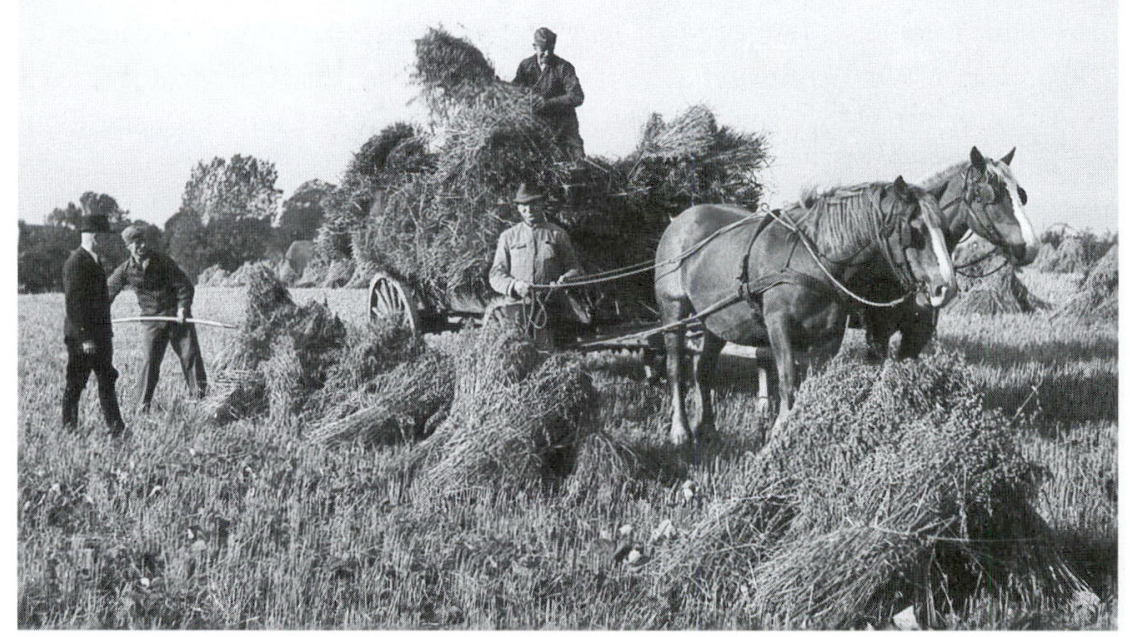

Mange hjem måtte modtage tyske soldater $i$ kvarter $i$ krigsårene. Rudolf Gimm optog en hel stribe fotografier, som skulle vise, at soldaterne blev modtaget med glade, og at de gjorde gavn. Her hjalper de med hostarhejde. Foto: Institut for sonderjysk lokalhistorie.

baglommen. Vi forhandlede om kristendommen og retten i situationen, hvad Regin Prenter ${ }^{25}$ så senere udgav som flyveblad.

Hjemmetyskerne optræder nu som bevæbnet politi i Tønder. Der går rygter om indkaldelse af »Selbstschutz« (Schleswigsche Kameradschaft) under overløjtnant Larsen, Skovby. ${ }^{26}$

17/2 rejste lærer Jessen til instruktionskursus i Haderslev. Skolen er lukket indtil videre.

24/2. Hele dagen overflyvning. Lille tysk jager går ned mellem Sdr. og Nr. Vollum, flyveren uskadt.

27/2 læstes biskoppernes fælles hyrdebrev ved gudstjenesten. ${ }^{27}$ En amerikansk bomber gået ned ved Højst. J. Brodersen averterer $\mathrm{i}$ aviserne om lastbiler til tyskerne. Han er ansat ved "Organisation Todt $\aleph^{28}$ med kontor i Struer, kører i flot bil.

$1 / 3$ begynder den tyske skole atter undervisningen.

$13 / 3$ var jeg til præstemøde i Gram menighedshus for at orientere om mødet i Dalum og den udsendte erklæring om retsforholdene. Der er atter kvartermagere i Bredebro. I kroen er et nyt hold lidt større drenge fra Hamborg ankommet.

$24 / 3$ var jeg til eksamen i den tyske skole. Riggelsen er nu blevet skoleforstander. Det hele var ret sløjt og stillestående. Vi fik kun serveret prøver i de 
to »kernefag« tysk og regning, ikke i religion eller historie. De store børn kan hverken dansk eller tysk, de mindre kan godt sige et tysk digt op, men vist uden indre forståelse, kun dressur, en kamp mod tusind år og moder natur.

$30 / 3$ henter tyske trainvogne fra Løgumkloster hø hos Chr. Matthiesen i Lund. 6/4 er atter 16 vogne undervejs for at hente et solgt hæs, denne gang hos Jens Fogtmann i Abterp, og 15/4 hos Jens Renlef i Abterp, som havde købt et hæs af Robert Fiedrich og gav føreren af kolonnen frokost bagefter.

Skærtorsdag (6/4) eftermiddag og aften fejredes Ungdomsforeningens 25års jubilæum $\mathrm{i}$ forsamlingshuset. Jefsen Christensen og Jakob Petersen talte, og mit festspil i 5 scenebilleder opførtes: 1. Foreningens stiftelse 1919. 2. Lykketiden i 20erne. 3. Landbrugskrisen i 30erne. 4. Det Unge Grænseværn og 5. Hitler-krigens udbrud. Der var indlagt adskillige smådigte i dialekt af bygmester Nielsen Jepsen. Grundtonen er danskhed og kristendom i forening for ret og sandhed, frihed og selvstændighed. I den øjeblikkelige modstandskamp mod nazismen skal enhver handle efter, hvad hans samvittighed byder ham, på åndens og ordets front for medmenneskelighed og mod umenneskelighed. Hjemlige amatører opførte stykket med liv og lyst. En meget vellykket fest for fuldt hus.

$17 / 4$ flytter den tyske skole til den nybyggede ejendom, med klasseværelset $\mathrm{i}$ storstuen og verandaen som forstue.

18/4 frigives forsamlingshuset igen. De tilbragte madrasser hentes igen. Indkvarteringen kom ikke. Jens Andersen uddanner nu rekrutter i Warszawa, skal hjemsendes til $1 / 5$ efter de lovede to års militærtjeneste. Niels Petersen er hjemme på orlov.

Den tyske skoleforening har holdt generalforsamling i skolen "mit sehr schlechter Beteiligung«, skriver den tyske avis. Chr. Riggelsen aflagde beretning, Broder Brodersen regnskabet. Lærer Jessen opfordrede til samling om skolen. P. Andersen takkede for imødekommenhed ved at stille lokale til rådighed $i$ en vanskelig situation efter branden.

$27 / 4$ kom to danske kriminalbetjente (Olsen og Himmelstrup fra København) til præstegården og spurgte efter præsten. Jeg var ikke hjemme og gik ikke hjem, før vor lokale betjent Feddersen var kommet hjem og havde forvisset sig om, at det var danske betjente og ikke Gestapo. Han kendte Olsen. Hele byen var i oprør, heldigvis uden grund. Det drejede sig om opklaringen af mordet på Kaj Munk, idet jeg havde fortalt om en hjemmetyskers udtalelser $i$ toget fra Aabenraa til Rødekro dagen før mordet (3/1): »Blot vi får præsterne væk, skal der nok komme ro i landet«. Jeg sad ved siden af manden i kupeen og reagerede med at sige, at jeg var præst, hvorefter samtalen naturligvis standsede.

29/4. De to tyske jernbanemænd på stationen, Faber og Schweiger, begge 
fra Bayern, er ikke nazister som Beck, der blev forflyttet. Der hentes nu fourage hos Ratenburg i Borg.

7/5 talte Magle og Tage Albertsen ved Grænseforeningens sendemandsmøde i forsamlingshuset om »Ejdergrænsen ifølge historisk ret«. Jeg lod dagen efter mit navn slette på medlemslisten. Samme dag var der hele dagen eksercits på den tyske sportsplads af drenge fra Tønder.

17/5. Jens Fogtmann leverer nu selv sit hø til tyskerne på stationen. Der var tysk hjemmeværn ${ }^{29} \mathrm{i}$ uniform på gaderne efter øvelsen i Løgumkloster plantage. Også andre danske bønder og håndværkere havde - mere i det stille - god afsætning til tyskerne af varer og tjente naturligvis godt på denne forretning.

Den tyske avis indeholder $1 / 6$ en artikel af lærer Jessen med titelen: »Für Dänemark mit Deutschland«. Der hævdes bl.a.: »Der allergrösste Teil der Bevölkerung unterwirft sich nicht nur in der Willensäusserung, sondern auch in der Willensübung der Macht eines anonymen geistigen Terrors ... Gegen diese terroristische Gruppe gibt es nur ein Mittel, nämlich den Kampf bis aufs Messer«. Der tales videre om »das bolschewistische Untier«, Tysklands beviselige respekt for andre nationaliteter, f.eks. også den danske. "Men Danmarks eksistens bevares kun i forbund med et stærkt og mægtigt Tyskland i et frit Europa«. Sådan vildleder man befolkningen i egen magtrus, der nu er ved at svinde. - Der var Gestapo-bil på »Stjernen«, vel som skræmmemiddel.

Lærer Jessen har fået tilsendt en pakke med 500 akselstykker og armbind til "Selbstschutz«, hvis leder han er på stedet.

19/7 blev seminarieelev Mads Nissen Styrk, Visby, arresteret i mosen.

20/7. Mislykket attentat på Hitler.

23/7-2/8 var jeg på cykletur til østkysten og fik adskillige informationer om stillingen, var bl.a. også med konservator P. Andersen i Frøslev for at se lidt nøjere på den nybyggede koncentrationslejr $\mathrm{i}$ landet. Chr. Riggelsen er indlagt på sygehuset med lungehistorie, vel forårsaget af nervepresset.

$5 / 8$ udlades et elitekorps, motoriseret, kommende fra Italien, på stationen. Skulle til Branderup. Skudklar »skrækpatrulje« i to biler på "Stjernen« i Bredebro.

21/8 udlades en transport biler på larvefødder på stationen. Den tyske lærer og B. var i travl virksomhed som vejledere. Befalingsmanden var på besøg hos B. - med store kasser, der fyldes med flæsk til den sorte børs. 28/8 ankommer 12 store antiluftskytskanoner og 3 haubitzere til stationen. De slæbtes i første omgang til Svanstrup skov. Ved vejene til kysten er der blevet opsat færdselstavler, langs jernbanen nye telefonledninger. Der ventes vel på invasion.

29/8 kl. 12 to minutters stilhed til minde og ære for de faldne for et år siden.

$1 / 9$ var der indkvarteringsfolk i præstegården sammen med sognefogeden, en løjtnant og en underofficer, artilleri. Kaptajnen (Pusch) anbringes i gæste- 


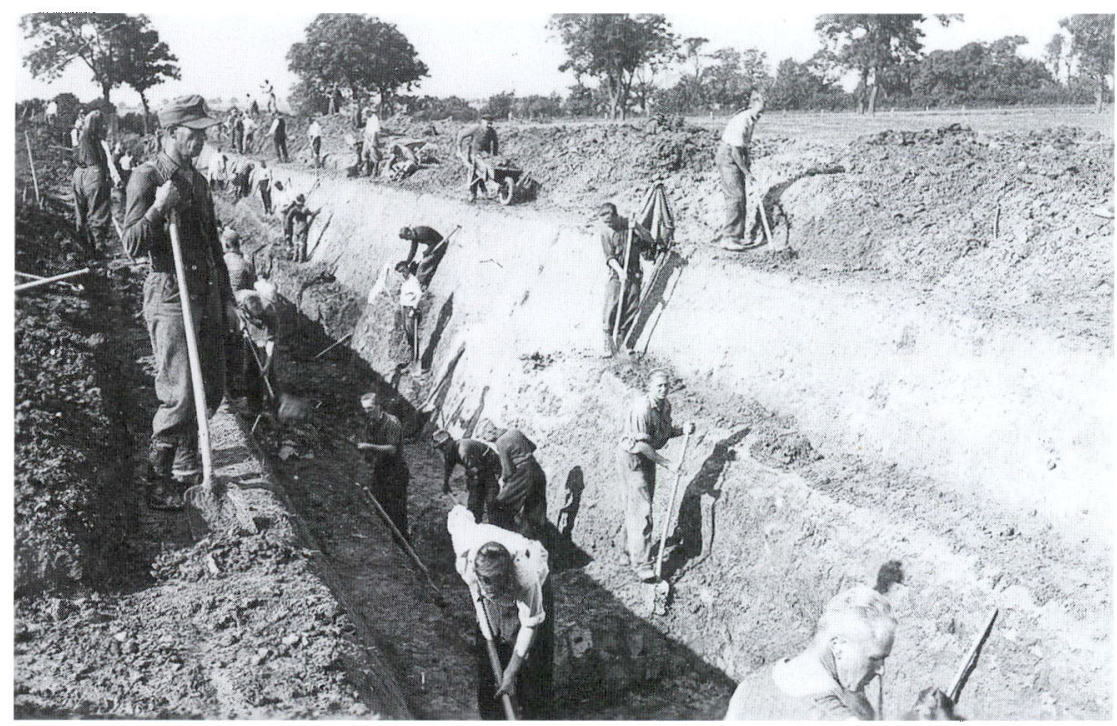

I 1944 måtte mindretallet i gang med omfattende skansearbejder. Her galder det Bau des Nordwalls ved Haderslev. Foto: Institut for sonderjysk lokalhistorie.

værelset, skrivestue i konfirmandstuen, mandskabet i forsamlingshuset og skolens gymnastiksal, kanonerne til Harres og Borg. 2/9 ankom de svære kanoner, forspændt med store prægtige jyske heste med nyt dansk seletøj. Mandskabet kom fra opløste afdelinger og skulle derfor ny indklædes her. Oppasseren Kochejda er fra Breslau, lokomotivfører, i sin tid på orlovstog mellem Polen og Østrig, nu åbenbart indstillet. 5/9 indlæsses kolonnen atter og går syd på om natten - til en uvis skæbne. Mandskabet i forsamlingshuset spurgte efter nyt engelsk radionyt. Enkelte gjorde sig »usynlige«.

9/9 er tyske hjemmeværnsfolk på skansearbejde nord på, nogle med vogn og heste. De vil meget nødig, "vil ikke grave i dansk jord ... aldrig i verden, når krigen alligevel er tabt « (Broder Brodersen). Ole Holm, som er vagtmand i uniform, er hjemme på orlov fra Aalborg. ${ }^{30}$ Vi taltes på gaden.

$12 / 9$ blev eleverne i den tyske skole sendt hjem midt på formiddagen. Med 3-toget tog en del spadefolk nord på, deriblandt lærer Jessen. Slagter Paulsen, Jacob Jessen og Hans Bjørnskov cyklede. Om aftenen kom kaptajn Böhme fra Lübeck i kvarter i præstegården, kommende fra Oksbøl. Mandskabet skal følge senere. 13/9 gik 20-30 panserbiler med toget nord på. Samtale med kaptajn Böhme, som var meget åben og indså vanviddet.

15/9 var der et døgns jernbanestrejke i Tønder og andre steder, ligeledes ved telefonen. Butikkerne var lukkede. ${ }^{31}$ 
16/9 transporteredes 21 tanks med toget syd på. Fra Oksbøl ankom 150 mand. 197 internerede i Frøslevlejren er imod aftalerne ført syd på.

18/9 havde jeg ved kaffebord atter en lang samtale med kaptajn Böhme.

$19 / 9$ afvæbnes det danske politi og gendarmeri og sendes syd på. Oprørende! Kaptajn Böhme hævder, at det tyske militær ikke har med den slags ting at gøre. De er Gestapos værk, som militæret ikke kan tage ansvar for. ${ }^{32}$

20/9. Sabotage sidste nat på jernbanen, både nord og syd for Bredebro. ${ }^{33}$

Indkvarteringen tager tilbage til Oksbøllejren. En premierløjtnant telefonerer til sognefogeden og spørger, hvad det er for et apparat nede ved broen $\mathbf{i}$ ån. »Da tickt etwas«, siger han. »Was ist das?« (tidsindstillet bombe?). En vandstandsmåler, lød svaret. Rør på. Hallucinationer altså.

24/9 oplæstes en erklæring fra »Præsternes Uofficielle Forening (Puf) ved gudstjenesten $-\mathrm{i}$ anledning af den sidste uges arrestationer, med henstilling om fasthed og besindighed. Kongens fødselsdag omtaltes. Biskopperne tier. Broder Ratenburg, P. Tarp og Aabling Matthiesen er nu endelig også taget afsted på skansearbejde. De kunne altså ikke undslå sig. Fritz Feddersen og Chr. Andersen, Bredebro, er i uniform (Zeitfreiwillige) til øvelse i Løgumkloster plantage.

26/9 stor flagning på kongens fødselsdag.

29/9 kom P. Tarp kørende med tysk soldat og et svin på vognen, nu altså ikke mere i nattens mulm og mørke, men i fuldt dagslys. En jernbanekolonne, polakker, som har arbejdet med anlæg af et stort vigespor ved stationen på den gamle Løgumkloster-strækning, er rejst på grund af manglende materiale.

\section{Gestapo-razzia}

Mandag 9/10 blev en sabotørgruppe i Bredebro revet op. Ved midnat blev postbud Jørgensen afhentet, mishandlet i kroen og ført til videre forhør i Kolding, om morgenen tømrersvendene Laue Bill og Niels Hansen hos bygmester Laust Jepsen, blikkenslagersvend Hans Petersen hos installatør Laust Jepsen, og regnskabskonsulent Magnus Thomsen. Ved lærer Jessens bistand blev de samlede i kroen og ført til Kolding til forhør og arrest. Man havde våben- og sprængstoflager gemt i Svanstrup skov og i Jepsens tømmerlager, men havde, så vidt vides, endnu ikke udført nogen sabotage.

$11 / 10$ blev igen en dramatisk dag. Gestapo kom om morgenen for at arrestere gårdejer Claus Clausen, Svanstrup, bilmekaniker Dela, Bredebro, og landmand Frands Jensen, Sdr. Vollum. De slap alle væk i sidste øjeblik og blev ikke fundet. Man truede med at sprænge Delas hus i luften, hvis han ikke viste sig inden middag. Fru Dela fik et nervechok og kom på sygehus i ambulance. Den unge fru Anna Nielsen, født Andersen, i kroen siges ikke at kunne holde ud til at bo der længere, efter at hun har hørt skrigene fra den torturerede 
Jørgensen. Dyrlæge B. udtaler åbent på gaden: »Der kommer mange flere med, de kommer »alle heran«. Det er et rak det hele, hele byen er eet komplot«. Hjemmetyskerne siger alle på rad: $» D e$ fik som fortjent og havde godt af den henfart«. Telefonisk opringning ved den tyske jernbanemand efter præstens henstilling stadfæstede, at de arresterede endnu var i Kolding i »Deutsche Wehrmachts Haftanstalt« (Koldinghus), at de ikke måtte modtage besøg, men nok få sendt tobak, frugt, toiletsager og skrivematerialer. Man skulle nok høre fra dem.

Prædiken om søndagen 15/10 var præget af det skete. Til stregen, men vel heller ikke over den. Den fandt god genklang i sindene.

Handelsmand Hans Petersen forsvandt 9/10, blev taget på »Tinglevhus« samme dag, men sendt hjem 15/10.

23/10 er de arresterede anbragt i Tønder tyske skole. De skal fungere som transportgidsler på strækningen Tønder-Varde, fem med hvert tog, ca. 40 ialt, deriblandt Braa Hansen, Haderslev, Erik Svendsen, Tønder, Egeberg Andersen, Tinglev, Lauritzen, Tønder, Riishøjgaard, Rise, her fra sognet Laue Bill, Niels Hansen, Hans Petersen, Magnus Thomsen, Hans Vagn Hansen, som blev taget i Rødekro. Alle pårørende har været i Tønder, talt med dem, og givet dem pakker, som de delte broderligt. De var ved godt mod. Vagten var forstående.

Landmand Kromann, Abterp, som nyligt har købt Sturms ejendom, da denne flyttede nordpå, vel af politiske grunde, har to sønner med i krigen. Hjemmetyskerne er ellers blevet meget tavse og tilbageholdende. De ønsker, at der ikke skal ske mere. De tænker vel på deres egen fremtid.

31/10 kom Mosquito-maskiner, der skulle angribe Gestapo-hovedkvarteret i Århus, i lav højde hen over egnen nord på.

5/11 er lærer Jessen og slagter Paulsen i uniform til øvelse i Løgumkloster. Det plejer at vare hele søndag formiddag.

$7 / 11$ foretog jeg om aftenen en vielse »under jorden« $\mathrm{i}$ gårdejer Niels Eilersens hjem i Storde, hvor datteren Marie uden forudgående lysning viedes til politibetjent Georg Valther Andersen fra Grenå, der er »under jorden« som sabotør i Horsens. Foruden forældrene var murermester H.P.Carstensen og hustru med som vidner. 8/11 talte jeg i »Ballumhus«, 11/11 på »Tønderhus«, $17 / 11$ i »Silkeborgsalen« (Ellehus skole).

$24 / 11$ fik vi om natten indkvartering $i$ byen af en formation fra Ishavsfronten, rejst igen $8 / 12$.

1/12 blev pastor Magle, Tønder, arresteret af Gestapo og ført til Frøslevlejren. ${ }^{34}$ Han var sammen med Helms og mig $i$ ledelsen af præsternes illegale front i Tønder provsti.

$16 / 12$ ytrer en tysk soldat, polak, at alle danske i byen er partisaner. Særlig 
præsten, tidligere tysk officer, skulle tage sig $\mathrm{i}$ agt. (Jeg havde intet med sabotage at gøre, førte kun ordets åndelige sværd, så godt jeg forstod det. En dag fik jeg dog besøg af en mig ubekendt person fra Astrup (Bjerrum), som formentlig var sabotør. Jeg forholdt mig reserveret og fik bag efter af Lorentzens på mejeriet nærmere oplysning om manden, der vist var lidt til en side). ${ }^{35}$ Der går nu vagt på banestrækningen, idet der går store transporter sydpå i disse dage.

22/12 er der stor afslutningsfest i den tyske skole. 23/12 var om natten kommet en SS-formation, som indkvarteredes i forsamlingshuset, gymnastiksalen og den tyske kro. Julefesterne måtte aflyses. En civilklædt, tidligere tysk soldat, med uniform under civiltøjet, hvad frisør Wandahl skal have konstateret, synes at være stikker i byen. Ved juleaftens gudstjenesten sad Jessens børn fra Åspe med deres barnepige ved siden af mig ved juletræet. Jeg lånte dem min salmebog.

27/12 rejste det østrigske »Edelweiss«-bjergartilleri syd på om formiddagen. I hele julehelgen var der vagt på jernbanestationen. Adskillige sørgede for anlæg af provisoriske beskyttelseshuler i tilfælde af bombardement, rutebilejer Snitgaard, Bredebro, endda udenfor byen på »Gallemark«.

\section{5}

\section{Flygtningeindkvartering}

7/1 blev et motoriseret SS-Edelweiss sanitetskompagni udladet på stationen og kørt til Bedsted.

Vi undlader $\mathrm{i}$ år at overvære undervisningen $\mathrm{i}$ den tyske skole. Ansøgningen om statstilskud anbefales nemlig denne gang ikke.

12/1 meddeles, at 300 internerede fra Frøslevlejren er deporterede til Tyskland (Neuengamme-lejren), deriblandt her fra sognet Hans Vagn Hansen, Hans Petersen, Magnus Thomsen (måske dem der har indrømmet deltagelse $\mathrm{i}$ aktiv sabotage). I forsamlingshuset oplæste jeg Hal Kochs 5 artikler om »Land og by« fra Berlingske Tidende 9-15/1.

Fra 1/2 standses al søndagstogafgang. 3/2 er der Gestapokontrol på »Stjernen « i Bredebro, føreren er i Sommer-uniform og dansktalende, ${ }^{36}$ bilerne standses og undersøges. Fra $4 / 2$ holdes gudstjenesterne foreløbig i skolen på grund af manglende brændsel. Broder Brodersen vil købe fedsvin hos naboen Chr. M. Hansen, men afvises. General Lindemann har afløst v. Hanneken. 8/2 er der vagt ved vejkrydsene og jernbaneoverskæringen og patruljer i gaderne.

Afstemningsfesten 10/2 kunne mærkeligt nok holdes i forsamlingshuset med tale af adjunkt Jørgen Andersen, Tønder, om Johs. V. Jensen. Da vi var kom- 


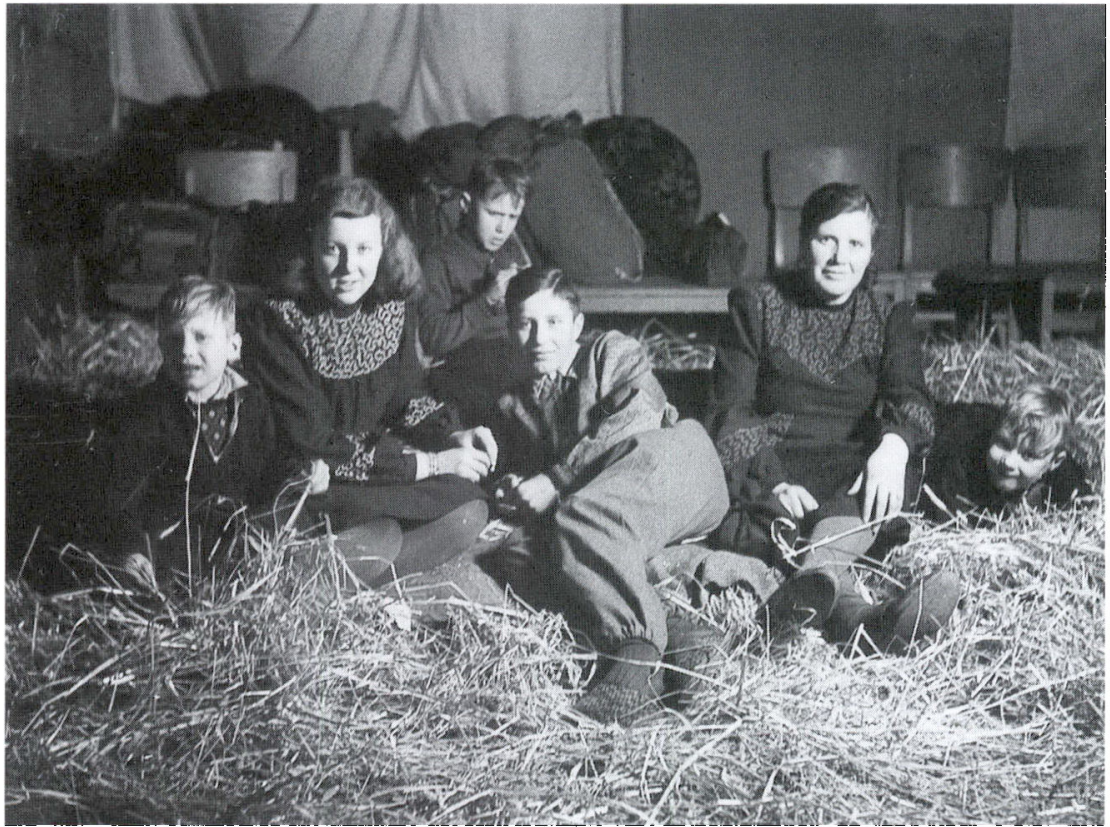

I 1944-45 strommede flygtninge fra de tyske ostomräder mod vest og en del nåede til Danmark. Pa dette nasten idylliske billede glader moderen sig over igen at vare forenet med sine 5 born. Foto. Institut for sonderjysk lokalhistorie.

met hjem, kom der opringning fra pastor Engsig-Karup, Horsens, om jeg ville meddele Ejlersens Georg Valther Andersens død (skudt under jernbanesabotage ved Horsens). Jeg cyklede straks derom med det tunge budskab.

12/2 spørger »Frauenschaft « om kvarter til tyske flygtninge fra østprovinserne. De »tidsfrivillige« har fået skriftlig ordre til at stille i Tønder inden 15/2.

$17 / 2$ ankommer de første tyske flygtninge til private tyske hjem i sognet. Forsamlingshuset, gymnastiksalen og hotelsalen beslaglægges med sygestue $\mathbf{i}$ konfirmandsalen. Sognerådet var til skattelægning i forsamlingshuset og bortvistes under protest. Jernbanevagten består nu af tysk-ukrainere. Vagtafdelingen er fra den danske skole nu anbragt i den tyske skole, der lukkes.

1/3 skød en 46-årig mand af vagtmandskabet i Nr. Vollum sig to kugler i brystet og døde. Fortvivlelse! Vagtkommandoen udskiftes delvis. Sabotage på jernbanen nord for Vollum station. ${ }^{37}$

Søndag 11/3 ankom flygtninge fra Stettin og indkvarteredes i massekvartererne. I nat opklæbedes Frihedsrådets plakater "Danmark kalder« over hele landet, også i Bredebro, hvor de fjernedes af tyskerne. Tyske soldater tager nu selv på »orlov« og indkvarterer sig i private hjem. Der var tre soldater (russere) 
i kirke i dag. De blev stående ved indgangen. Før den danske gudstjeneste var der tysk konfirmation.

$17 / 3$ kom Chr. Riggelsen til præstegården for at forhandle om flygtninges anbringelse i private danske hjem - af menneskelige grunde. Vi havde en lang samtale, hvori han til tider var grædefærdig. Jeg frarådede frivillig indkvartering. Man måtte afvente en fælles dansk stillingtagen, forlange bedre menneskelig behandling af vore internerede i Tyskland, skulle også tænke på at kunne modtage egne danske evakuerede, når situationen krævede det. Rømningen af massekvartererne ville kun medføre, at der kom nye flygtninge, hvad sognet $i k k e$ skulle være interesseret $i$. De led jo ingen nød $i$ kvartererne, når de fik logi og mad. I nødssituationer ville danskerne naturligvis altid hjælpe de nødstedte. Jeg viste ham sidste meddelelse om 7 frihedskæmperes henrettelse, deriblandt læge Teilmanns søn, hvis far havde været vikar her, og som han kendte. Der var ikke noget at sige til, at besættelsesmagten tog danske sabotører til fange, men de skulle behandles efter folkerettens love. Han nævnte, at han kun var formand for den tyske skole og ellers ikke havde med noget at gøre. Jeg måtte ikke fortryde på hans hjælpeaktion, krigen kunne vare længe endnu, hvad jeg dog ikke troede.

$18 / 3$ er de »tidsfrivillige« i fuld udrustning på gaderne, efter øvelse i Løgumkloster. Efter gudstjenesten besøgte jeg den ene mandskabsstue i skolen og spurgte, om de var interesserede i en tysk gudstjeneste i påsken. Det var de, både protestanter og katolikker, dog ikke til fælles altergang. De sang for mig "Grosser Gott, wir loben dich«. Jeg bad dem fremsætte deres ønske gennem deres befalingsmand, da det ellers kunne misforståes og føre til ubehageligheder. Der fremkom imidlertid intet ønske. Kommandoføreren har vel ikke syntes om en sådan henvendelse til den danske præst på stedet. Lørdag aften talte så i stedet "Asmus von der Heide« for flygtninge og andre i den tyske kro.

Hele kommuneskolen i Bredebro er nu beslaglagt til flygtninge, som tilses fra Tønder. 23/3 var en tysk sygeplejerske (Schwester Renate), som havde fået overdraget tilsynet med flygtningene $\mathrm{i}$ byens forskellige lejre, $\mathrm{i}$ præstegården sammen med to små blege drenge. Hun spurgte efter den tyske præst på stedet, hvor jeg måtte henvise til pastor Raun i Løgumkloster. Hun var reformert, fra Hamburg-egnen, så rent »menneskeligt« på sagen. Hun ville gerne have overladt et skab til sine sager i forsamlingshuset (hvad jeg siden sørgede for), bad også om lidt tysk læsning til »dannede« folk, hvad hun fik og blev meget taknemlig for.

26/3 begravedes den tyske flygtning Max Lüdke fra Stettin, der fra lejren i skolen var blevet indlagt på Løgumkloster sygehus og død der, ved pastor Raun. Han bragte selv dødsattesten til præstegården. P. Andersen kunne ikke lade være med at "heile« ved graven. 


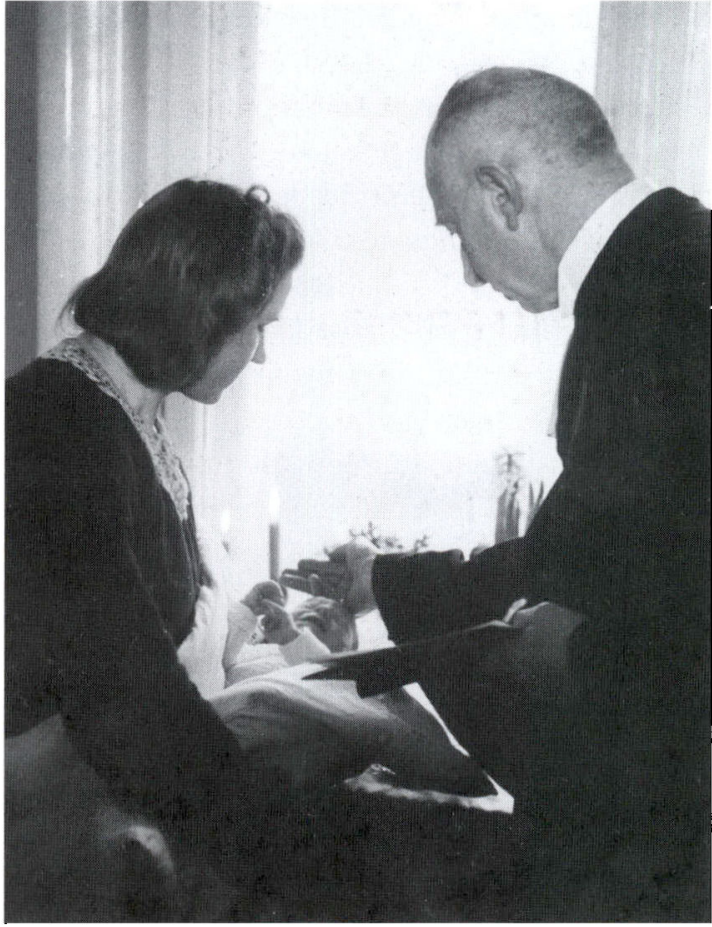

De mange tyske flygininge skabte behov for sarlige kirkelige handlinger og tyske gudstjenester. På flygtningehjemmet Laimun ved Aabenraa var der tysk barnedih. Foto: Institut for sonderjysk lokalhistorie.

1/4 var en ukrainer-soldat til gudstjeneste. Han blev efter gudstjenesten og ville gerne tale med præsten. Han var i stor uvished, fortalte han, om sin hustrus og 4 ukonfirmerede børns skæbne, ville så gerne se dem igen. Han henviste til skriftordet $»$ Hvad to eller tre beder om i mit navn, det vil jeg give dem« og ville nu gerne, at vi bad sammen for familiens velgående. Det gjorde vi ved alterets knæfald. Han var meget bevæget og takkede mig for bønnens hjælp.

6/4 har den tyske lærer igen begyndt undervisningen i privatskolen, efter at banevagten er rejst. Den danske skole må benytte privatlokaler til undervisningen, bl.a. konfirmandsalen, hvor man så deler i formiddags- og eftermiddagshold.

$8 / 4$ er der sabotage på jernbanen syd for stationen. Ved kirken kom før gudstjenesten en ældre herre hen til mig og præsenterede sig som tysk flygtning, baptistpræsten Strehlow fra Elbing i Østprøjsen, 70 år, født i Berlin. Han havde i Løgumkloster, hvor han var i lejr, med kone og yngste gravide datter, efter en farlig skibsfart over Østersøen, besøgt provst Schülein og pastor Raun. Han viste skrivelse fra baptistpræsten i København. Det opklaredes nu, at det 
var baptistpræsten i Rødekro (ikke Bredebro), han ville opsøge. De ville ellers helst være blevet hjemme i Østprøjsen, men dreves afsted. Han gik så tilbage til Løgumkloster, efter at have afslået en forfriskning, som jeg ville skaffe ham. Tiltalende og åben.

Gestapo-bilen Z 14 er i byen. Lærer Jessen, Ratenburg og den tyske jernbanemand Schuchert på stationen var tilkaldt til konference i den tyske kro kl. 17.

11/4 kom mange tyske rekrutter til byen, som nu skal være garnison med uddannelse. Også Borg skole blev beslaglagt til rekrutkvarter.

15/4. Luftangreb på stationen i nat, hvor sporskiftet mod syd blev ramt og ødelagt. Til aften var der to løjtnanter og tre underofficerer for at se på det beslaglagte værelse til en officer, premierløjtnant Kellermann, som dog ikke kom, men foretrak at bo på hotellet. Ordføreren hed Sommer. Han gav hånd, en anden »heilede $\ll$.

16/4 var der om formiddagen jernbanesprængning mellem Bredebro og Døstrup. Ny banevagt. Alle blev visiterede ved indgangene til byen i nat. 18/4 blev jeg på en cykletur til Døstrup visiteret tre gange af patruljer. »Wie viel Zünder haben Sie in der Tasche«, spurgte man. »Kommen Sie, nehmen Sie alle mit«, svarede jeg.

Slusen ved Ballum er nu blevet lukket af militæret. ${ }^{38}$ Vandet $i$ åen stiger. Fra $19 / 4$ indstilles al regelmæssig jernbanetrafik. Vagtmandskabet er igen blevet udskiftet (kan man måske ikke stole på dem?). I nat lå ca. 100 mand i ventesalen på stationen.

20/4 (Hitlers fødselsdag) er hagekorset hejst på kommuneskolens flagstang, ganske vist med hovedet nedad, hvad man ikke selv havde været opmærksom på, men førstelæreren opdagede det. Senere hen blev det efter sognefogedens henstilling flyttet til den tyske privatskoles flagstang lige overfor. Rekrutterne aflægger faneed på skolens legeplads, hvor også en hagekorsdekoration er sat op. En del »tysk-arbejdere « går ledige på gaden. De tør ikke mere tage til Skrydstrup flyveplads på arbejde. General Lindemann kom igennem byen fra Ballum, har vel været ved slusen og set på oversvømmelsesforanstaltningerne.

23/4 er lærer Jessen taget afsted med bil til Tinglev. Løjtnant Glück, kemistuderende fra Nürnberg, 24 år, er kommet i kvarter i præstegården. Kl. 19 fløj ca. 15 allierede maskiner $\mathrm{i}$ forholdsvis lav højde følgende hovedvejen nordpå og beskød lastbiler på vejen. ${ }^{39}$

De tyske hjemmeværnsfolk har nu fået valget mellem at gå ind $\mathrm{i}$ "Hipo« (Hilfspolizei) eller hjemsendes. De valgte alle det sidste.

24/4 k1. 11 blev førstelærer H. L. Henriksen, Bredebro, arresteret af Gestapo og ført til Kolding. En SS-officer optrådte nærmest sindssygt hos læge Schultz. Han havde mistet alt, kone og børn, og ville gerne skydes og selv dø. Der 
anlægges nu befæstninger på Gasse-højene. Løjtnant Glück, der i samtale udtalte, at han stadig troede på Tysklands sejr og regnede med det store afgørende modstød, når fjenden var kommet ind midt $\mathrm{i}$ Tyskland, er flyttet til et nyt kvarter i Bredebro. Han stammede fra et evangelisk hjem, men havde udmeldt sig af kirken og »kunne vel godt være en kristen for det«.

26/4 kom vor datter Signe med sidste kørende tog fra København til Bramminge, gik derfra med andre til fods til Ribe, overnattede på stationen og kom til Bededags formiddag hjem med tog fra Ribe. $28 / 4$ er der tysk appel om aftenen i den tyske skole. Ballum sluse er igen åbnet, dog kun så meget, at vandstanden kan kontrolleres. 30/4 er den atter lukket. Vandstanden skal nå åkanten, så engene kan oversvømmes med korteste varsel. 29/4 var der ungdomsgudstjeneste i kirken om aftenen ved pastor Ebbesen, Døstrup, og mig.

\section{Befrielsen}

1/5 ringede provst Schülein og gav biskop Scharlings opringning videre: »Tillykke med dagen, Krigen er slut. Ringning med kirkeklokkerne efter officiel besked enten kl. 15 eller $18 \mathrm{i}$ dag eller kl. 8 i morgen, takkegudstjeneste søndag $6 / 5$ - efter samråd med de øvrige biskopper«. Det var en forhastet meddelelse.

Dyrlæge B.s kontorvindue blev slået ind i nat. $2 / 5$ blev B. i sin jumpe af en anden vogn trængt ned $\mathrm{i}$ vejrabatten med pisk til hesten. Ungdommen i Bredebro har været udfordrende i de sidste to nætter. Jeg må vist sige noget herimod på søndag i kirken. Der flages på halv stang i dag ved den tyske skole (Det viste sig at være $\mathrm{i}$ anledning af meddelelsen om Hitlers død). En 4-mands patrulje går gennem byens gader.

3/5. I nat blev 4 mand banket op i Bredebro og taget med af det tyske feltpoliti til Aabenraa, nemlig Magnus Hansen, Alfred Hansen, Niels Hansen (deres far) og Johan Jacobsen. Hos købmand Aabling blev huset gennemsøgt, medens købmanden stod med ansigt og løftede hænder mod muren. Aktionen gjaldt Svend Aage Hansen, som dog ikke fandtes. Vi forhandlede med militæret på hotellet om deres frigivelse. De vendte da hjem om eftermiddagen. Bentin var ikke indforstået med lærer Henriksens arrestation, efter hvad han ytrede overfor lærer Borst, hans skolekammerat.

Garnisonen alarmeres om aftenen og marcherer til Gasse-stillingen ved Skærbæk. Broen over åen er undermineret. Der er to-mands vagt på telefoncentralen (løjtnant og sergent).

4/5. To »strejfere«, løjtnant Jordan og feldwebel Helwing, meget beskedne folk, som havde indkvarteret sig selv i præstegården, tog afsted tidlig om morgenen kl. 6. De ville med tog til Tyskland. Lærer Henriksen og flere, deriblandt pastor Petersen, Hostrup, og lærer Jepsen, Løgumkloster, blev frigivet i Kolding ved middagstid. Fru B. græder. 


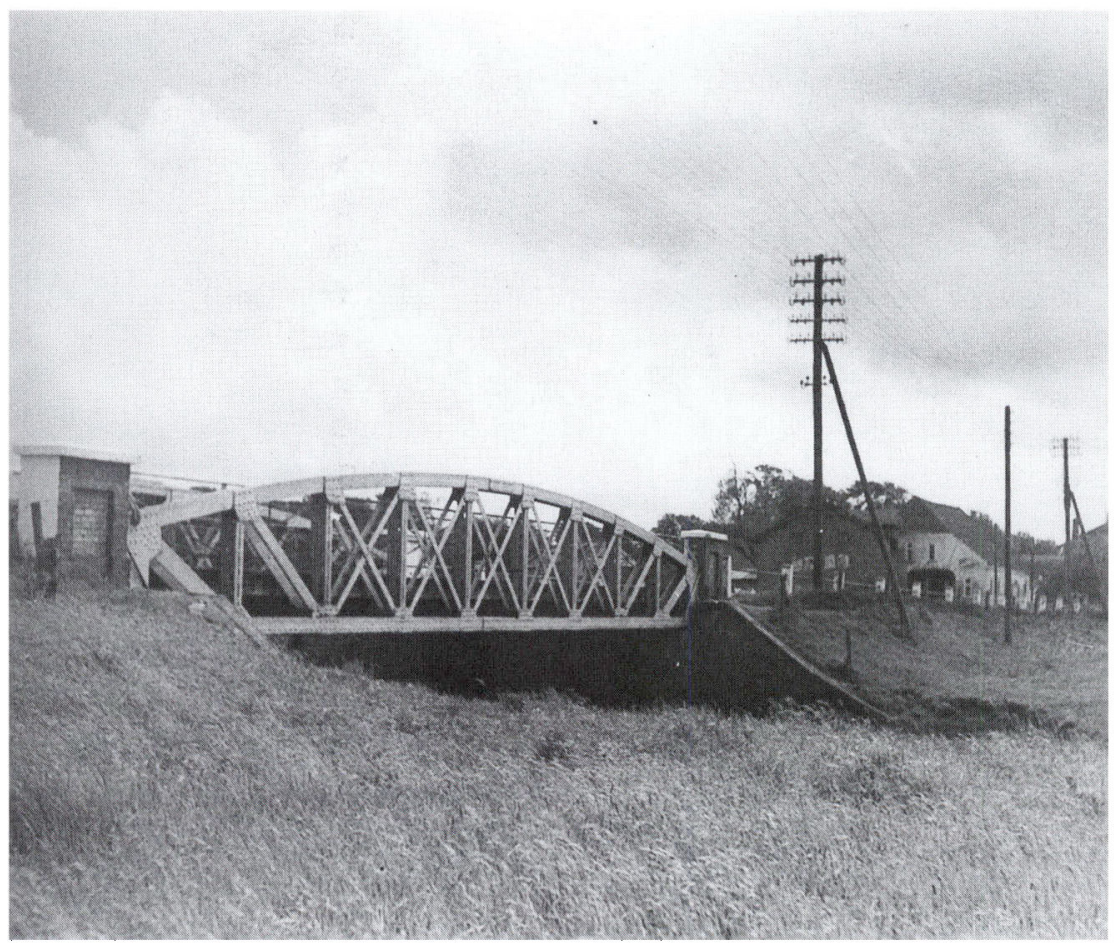

I dagene 3.-5. maj 1945 gik der rygter om, at tyskerne ville sprange broen over Brede a. Takket vare initiativ fra lokale folk blev det dog forhindret. Billedet her er optaget den 12.juni 1944 af larer Rudolf Gimm fra Bolderslev, som arbejdede som fotograf for NSDAPN's billedarkiv. Foto: Institut for sonderjysk Lokalhistorie.

K1. 20.45 kom meddelelsen fra London om den tyske kapitulation. Flagene gik til tops. Sammen med Gantzel drak jeg et glas vin hos kommunekasserer Wind på kirkepladsen. Det var befriende. Gaderne var fyldte med glade mennesker.

$5 / 5 \mathrm{kl} .8$ rejses flagallé med guirlander ved hovedgaden syd på med transparent "Wellcome to Denmark«. Der gik rygter om, at en i aftes ankommet ung SSløjtnant, der i nattens løb med sin sprængningstrop havde lagt sprængladning under broen og landminer langs åen, endnu ville sprænge broen i luften. Gantzel, P. Nicolaisen, Kummerlev, og jeg gik da til kommando-kvarteret på hotellet og fik foretræde hos den tiltalende premierløjtnant Kellermann med anmodning om at forhindre det meningsløse hærværk. Han tilkaldte løjtnanten, mens vi var der. Og ladningen blev uskadeliggjort, ligesom landminerne. Lærer Henriksen kom hjem om eftermiddagen, hans fødselsdag. De tre internerede i Frøslevlejren, A. Jørgensen, Laue Bill og Niels Hansen kom om aftenen og blev båret $\mathrm{i}$ 


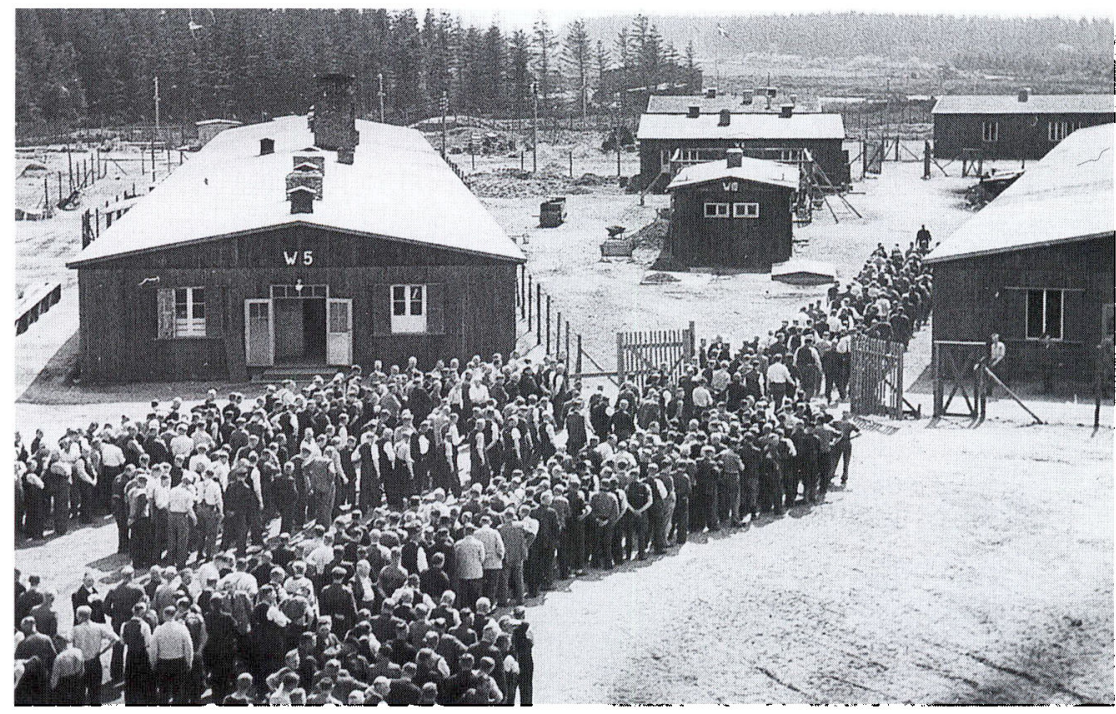

Fårhuslejren. Skonsmassigt blev 3.000 hjemmetyskere interneret i Fårhuslejren i befrielsesdagene. Her ses internerede på vej til spisning. Foto: Frøslevlejrens Museum.

guldstol gennem byen. To Hipo-mænd fra Tønder var om morgenen kørt tør for benzin ved Vollum, bad forgæves om benzin i Bredebro og gik så til fods til Ribe, hvor de blev arresterede. De ventede engelske tropper kom ikke idag.

Søndag 6/5 var der befrielsesgudstjeneste med stopfyldt kirke, ca. 500. Der var pyntet med grønt og blomster og opsat flagstandere undér korbuen. Det tyske militær er overalt i opbrud syd på i kolonner og enkeltvis, i bil, på cykel og til fods. Hjemmetyskerne er nedslåede og afventende, hvad der nu vil ske med dem. 10/5 er den danske befolkning i stort tal samlet på "Stjernen « om eftermiddagen for at modtage de bebudede engelske tropper. Der kom kun een gastesoldat $\mathrm{i}$ bil, som naturligvis blev modtaget med stor hyldest.

\section{Interneringer}

Samtidig blev af byens frihedskæmpere under kommando af bylederen, konsulent Laue Nørgaard, Svanstrup, hvis søn Mathias havde været interneret af tyskerne, 22 hjemmetyskere afhentede og under folks mishagsytringer kørt bort i rutebil til Tønder og derfra til Frøslevlejren, som nu kaldtes Faarhuslejren. Det var følgende: Broder Ratenburg, P. Tarp, Hans Bjørnskov, P. Tychsen, Borg, Jacob Jessen, Aaspe, Willms, J.S. Brodersen, Jens Brodersen, Søren P. Hansen, Fritz Feddersen, Karl Feddersen, P. Andersen, Chr. Andersen, Andreas Motzkus, Hans Beier Hansen, Andreas Beyer Jacobsen, Nis Paulsen, Carl Rosenberg, Bernhard Schmidt, Bredebro, Chr. Riggelsen, Kummerlev, 

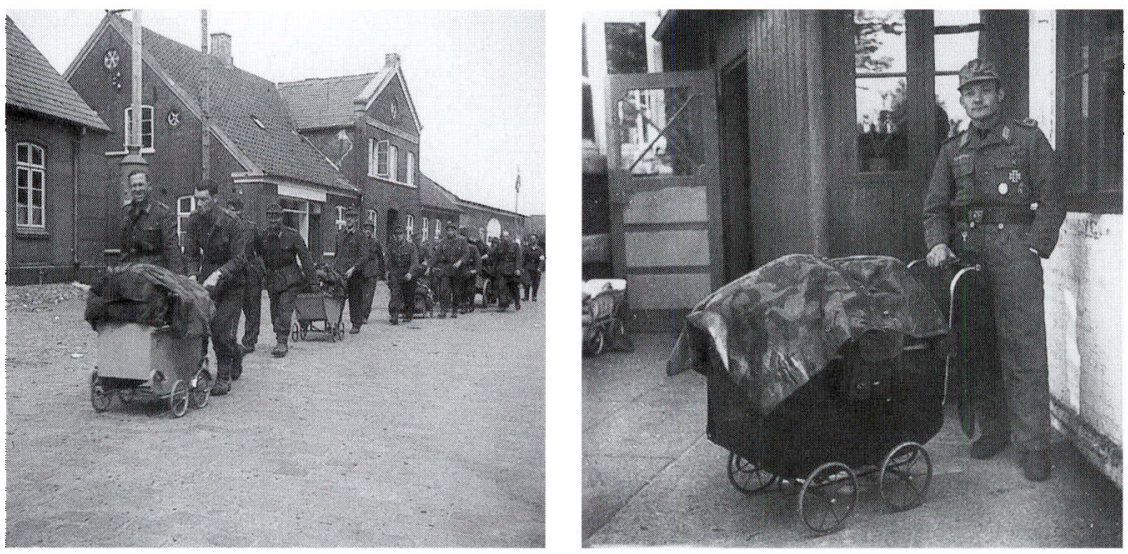

Efter Befrielsen i Bredebro. Tyske soldater i Kirkegade på vej sydpå. Foto: Lokalhistorisk Samling Bredebro.

P. Bentin, Brede, Andreas Jensen, Rasmus Knutzen, Harres. - P. Rosenberg, som ved en navneforveksling var kommet med til Tønder, fik sognepræsten ved opringning og forklaring til arresten i Tønder frigivet og sendt hjem 16/5.

Andre var på arrestationslisten, men fandtes ikke. Ved et indkaldt møde på hotellet dagen efter af ledende danske i sognet gik Gantzel og jeg ind for, at det nu måtte være nok med arrestationer. Adskillige "småfolk « burde slet ikke være taget med. Man havde ialt ca. 70 navne på listen, som var opsat ved hjælp af to politibetjente, der havde opholdt sig »under jorden « i private hjem i sognet et stykke tid. Da ledelsen holdt på, endnu to mand skulle afhentes, henstillede vi kraftigt, at det ikke skete. Og man fulgte henstillingen.

I den tyske kro er der indrettet en lejr for 85 russere, som er blevet anvendt til arbejdstjeneste. Af disse var en tiltalende lærerinde med to børn og en anden kvinde i kirke i dag (13/5). Jeg havde en samtale med lærerinden, der talte godt tysk. Hun tog sig af sine forhutlede landsmænd. Der er også en afdeling ungarere i kvarter i byen. De venter på hjemsendelse. Natten til 12/5 lå et regiment $\mathrm{i}$ bivuak her i sognet på march syd på. Der var også danske sydslesvigere med, nemlig H. Bøwadt, Flensborg, Andresen, Harreslev mark, og Mathias Nielsen, Ladelund, som tog over grænsen med deres afdelinger.

$15 / 5$ var jeg i bil til Horsens for at forestå G.V.Andersens begravelse fra klosterkirken. David Jensens og hans lig var fundet i et krat ved Bygholm slot.

$16 / 5$ kom nye tyske tropper på gennemmarch syd på i bivuak natten over, en kaptajn Jansen fra Rhinlandet i kvarter i præstegården. Det endte med, at om aftenen en flygtningekvinde fra Stauning, der udgav sig som telefonistinde ved staben, blev vist ud af huset, og næste morgen selve kaptajnen, fordi han 

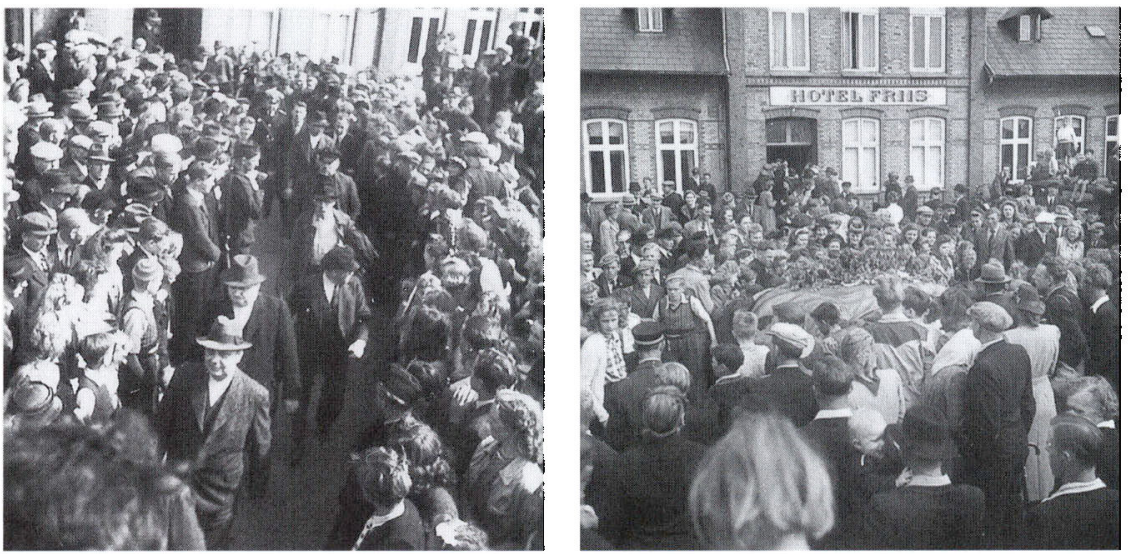

Hjemmetyskere må gå spidsrod gennem den ophidsede menneskemangde ud for Hotel Friis (senere Bredebro Jernbanehotel) på vej til internering. Episoden er et typisk udtryk for befrielsesmånedens ophidsede stemning. Foto: Lokalhistorisk Samling, Bredebro.

havde krænket gæsteretten. Han blev sur og gik sin vej. En fru Sabro, der foregav at stamme fra Danzig og havde efterladt to børn i Stauning, blev anholdt af feltpolitiet og sendt nord på igen.

$17 / 5$ kom efter invitation en engelsk afdeling på ca. 30 mand i 5 vogne, anført af en løjtnant, hertil fra Skærbæk. Vi modtog dem kl. 14.30 ved Svanstrup og gik $i$ optog med faner og skolebørnene $i$ spidsen ind $i$ byen, hvor lærer Henrik Petersen, Abterp, stående på en panservogns kølèr, holdt en tale på engelsk til vore befriere. Løjtnanten svarede kort. Derefter gik optoget gennem byen ned til læge Schultz’s palæ, efterhånden med en del børn og unge oppe at køre. Derfra tilbage til hotellet, hvor der var dækket bord med øl, snaps og snitter. Lærerne Petersen og Andresen talte og den engelske løjtnant, bistået af en tolk i CB-uniform, svarede. Kl. 16 kørte englænderne videre i retning af Ballum. Alt forløb værdigt og hjerteligt, et møde mellem England og Danmark, to beslægtede folk med samme demokratiske frihedstraditioner.

Ved gudstjenesten $20 / 5$ bød vi velkommen til de 17/5 aften fra Tyskland hjemvendte internerede frihedskæmpere Magnus Thomsen, Hans Petersen, Thorkild Bjørnskov og Hans Vagn Hansen. Kirken var smukt pyntet. Indsamlingen til menighedsplejen i Flensborg gav $225 \mathrm{kr}$.

21/5 kom en tysk præst, Kersten, flygtning i Aabenraa-lejr, stammende fra Kalisz-egnen i Polen, og ville holde gudstjeneste i kirken for flygtningene. Hans papirer med tilladelse hertil stammede dog fra »Wehrmacht « før kapitulationen og et dansk kontor i Aabenraa. Han ville ikke henvende sig til de danske myndigheder, som jeg anbefalede ham. Han kom fra Visby, hvor han havde holdt guds- 
tjeneste, sagde han, og ville til Løgumkloster om eftermiddagen. Forud havde han rejst på østkysten mellem Sønderborg og Christiansfeld. Jeg henviste ham da til at samle sine folk i skolen her, hvor en af flygtningelejrene jo findes, hvad han så måske har gjort. Men ved kirken mødte en trop tyske soldater op med en løjtnant i spidsen og flygtningedrengene fra den tyske kro med deres lærer Krüger og kone som ordførere. De mente, at der skulle være tysk gudstjeneste i kirken, men blev så henviste til skolen. Det hele syntes at være ordnet på egen hånd.

$5 / 6$ rejser de hos hjemmetyskere privat indkvarterede flygtninge til Oksbøllejren. Her findes nu lejre i forsamlingshuset, gymnastiksalen og to klasseværelser. I kroen er der stadig tyske drenge og ca. 80 russere og polakker, som vist skal til Blåvand. Nogle af de arresterede hjemmetyskere begynder at vende hjem, som den første $\mathrm{H}$. Beier Hansen 4/6. I eftermiddags var der stort folkemøde ved "Højen« syd for Brede by, flagallé fra Bredebro og helt derop, optog fra "Stjernen« med musik i spidsen, taler af højskoleforstander Haarder, Rønshoved, om folkestyrets forudsætninger, konsulent Thomsen om sine oplevelser i KZ-lejrene Frøslev, Neuengamme og Harburg-Hamburg, pastor Steenberg om befrielsen og fremtidsopgaver, især overfor mindretallet og Sydslesvig.

$7 / 6$ rejste jeg på en uges besøg i København, opsøgte bl.a. biskop BruunRasmussen for at tilbyde mig til tjeneste i Sydslesvig. Søndag $1 / 7$ holdt jeg på eget initiativ gudstjeneste på tysk for flygtningene $\mathrm{i}$ en tom skoleklasse. Der var taknemmelighed for tjenesten. 5/7 flyttedes flygtningene fra skolen til baraklejren nord for Tønder. Russerne i kroen er rejst. Drengene skal til »Hohenwarte« ved Højer.

$8 / 6$ holdt jeg om eftermiddagen flygtninge-gudstjeneste i Visby konfirmandstue efter anmodning fra sognepræsten N. Søe. Modstandskontoret i Tønder havde i første omgang i samråd med provst Schülein forbudt mig at tage til Visby, men afstod fra forbudet efter min samtale med provst Schülein.

17/6 var Det Unge Grænseværns stævne på Dybbøl, 24/6 modstandsbevægelsens på Skamlingsbanke, 11/7 nationalt stævne på Dybbøl, hvor dronningen og kronprinseparret var til stede.

Flygtningegudstjenesterne i Bredebro og Visby fortsattes. I Brede forsamlingshus, hvor de holdtes i den lille sal, var der en vis opposition, uvist af hvilken årsag, medens enkelte var meget taknemmelige, ligesom i Visby. 28/9 flyttedes de sidste flygtninge fra forsamlingshuset til lejren ved Tønder, hvor jeg også lejlighedsvis kom på besøg og hilste på enkelte bekendte.

\section{Retsopgør}

30/7 sendte jeg dommer Blehr, Løgumkloster, nu Sønderborg, et længere brev med henstilling om hjemsendelse af de små og ufarlige "syndere« fra Faarhuslejren. Det lød: 
»Til hr. dommer Blehr, Løgumkloster. - Hr. dommer. På en cykletur i den forløbne uge har jeg haft lejlighed til at drøfte interneringsspørgsmålet med en del ledende mænd i grænselandet, præster, politikere, forhenværende (danske) internerede (civile og militære), alle med tilknytning til modstandsbevægelsen. Under indtryk af disse samtaler tør jeg vist fremsætte følgende som det almindelige syn på spørgsmålet. Som udenforstående kan og skal jeg naturligvis ikke blande mig i den kriminelle side af sagen, men denne har også en politisk side, som jeg gerne vil sige lidt om. Det synes så, som om det psykologiske øjeblik for hjemsendelse af de menige internerede nu er inde. Sindene er kommet noget til ro og begynder at kunne se sagen også fra modpartens side. Vi kan ikke være tjente med at få disse vore hjemmetyske landsmænd gjort til politiske martyrer og forbitrede modstandere, når vi dog siden skal leve sammen med dem og eventuelt håbe på at vinde dem med tiden. Når endvidere enkelte af deres fæller allerede er blevet hjemsendte, må det virke som dansk vilkårlighed, at de selv stadig sidder og måske slet ikke endnu er kommet $\mathrm{i}$ forhør. ${ }^{40}$ Dertil kommer, at høsten er begyndt, og de fraværende landmænd savnes stærkt på deres ejendom. Man behøver vist ikke at frygte for, at den løsladte forsvinder, hvis hans sag på nærværende tidspunkt ikke kan færdigbehandles.

Med hensyn til »Heimwehr«-folkene, som i og for sig vel må bedømmes hårdere end de frivillige ved fronterne, tør det vist hævdes, at disse aldrig ville være trådt $\mathrm{i}$ aktion på det sene tidspunkt af krigen. En enkelt skal før sin internering have udtalt, at man i april 45 alle nægtede at lade sig sende til fronten, hvorefter den militære ledelse dekreterede deres hjemsendelse. Der må i spørgsmålet muligvis tages hensyn til hjemsognenes stilling i national henseende. Et mere rent dansk sogn absorberer lettere de hjemvendtes ressentiment end et mere blandet, og kan derfor også bedre magte opgaven straks og på een gang. Tiden synes i hvert fald at være inde til, at de menige blandt de internerede hjemsendes nu - for så vidt på samme tidspunkt som modstandsbevægelsens folk.

Til eventuel orientering tillader jeg mig at vedføje en lille karakteristik af de internerede fra Brede sogn:

Chr. Riggelsen, Kummerlev, gårdmand, nazistisk medlem af sognerådet, formand for den tyske privatskole, "Heimwehr«, af hjemmetysk slægt, men ellers en dygtig landmand og et respektabelt menneske, f.eks. ikke sortbørs-mand.

P. Tarp, Borg, husmand, økonomisk altid i forlegenhed, og på den konto vel havnet $\mathbf{i}$ »Heimwehr« og ved skansearbejde, ufarlig i enhver henseende.

Hans Ipsen Bjørnskov, Borg, ugift og hjemme på husmandsejendom, var aldrig selv kommet med til noget, hvis ikke forældrene havde sendt ham, ufarlig i enhver henseende.

Andreas Jensen, Harres, gårdmand, velstillet, trak sig tilbage som formand for den tyske skole, som han var blevet udnævnt til, ellers ikke med i noget, noget kras, men ingen dårlig karakter. 
Aaling Matthiesen, Harres, gårdmand, vagtmand, ekonomisk altid i trang, konen den drivende.

Kromann, Abterp, ugift, har været ved fronten, men ellers ikke kendt på stedet, da forældrene lige er tilflyttet.

Bernhard Schmidt, Bredebro, sadelmager, har vist haft lidt værnemagtordrer, men ellers ganske uden tysk aktivitet, ufarlig, konen derimod tysk aktiv.

Chr. Andersen, Bredebro, landmand, hjemme, ugift, »Heimwehr«, kun med på forældrenes initiativ, ufarlig. Broderen Jens Andersen været to år på østfronten, men hjem 1/5 $44 \mathrm{og}$ nu interneret nord på.

Fritz Feddersen, Bredebro, radiomekaniker, ugift, »Heimwehr« på forældrenes initiativ, måske ikke helt ufarlig i fremtiden.

Søren P. Hansen, Bredebro, husmand, vagtmand, har vist kun været ude om at tjene penge, ellers stilfærdigt menneske.

Karl Feddersen, Bredebro, slagtermester, ugift, dygtig, reel og respekteret af alle på stedet, politisk tilbageholdende, har muligvis tilskudt penge.

Nis Paulsen, Bredebro, slagteriudsalg, ugift, tilflyttet, har vist tjent godt på kødsalg til værnemagten m.m., "Heimwehr«, tysk statsborger.

Jens Brodersen, Bredebro, købmand, ugift, invalid fra sidste krig, altid været tysk og hæudet dette, noget kras, men ellers ikke med i noget.

Peter Paulsen, Bredebro, mælkehandler, har vel drevet nogen sortbørs handel, konen ægte dansk og børnene ligeså.

Alle de nævnte synes jeg kan hjemsendes uden risiko, især efter at så krasse folk som gårdmand Jakob Jessen, Aaspe, og dyrlæge B., Brede, er hjemsendt på et ret tidligt tidspunkt, og endvidere også gårdmand Broder Brodersen, Brede, og montør Chr. Nicolaisen, Bredebro, er kommet hjem.

Derimod har jeg betænkeligheder ved følgende: Broder Ratenburg, Borg, gårdmand, som har haft en ledende stilling som »Ortsgruppenleiter«, og Rasmus Knutzen, Harres, gårdmand som aldrig har været noget fint papir, og P. Andersen, Bredebro, gæstgiver, om hvem det samme gælder. At lærer Jes Jessen, Bredebro, hovedagitatoren og Gestapo-håndlangeren på stedet, og købmand J.S. Brodersen, storentrepenøren, skal afvente deres dom i interneringslejren, er der sikkert almindelig ønske om.

Jens Holdt, sognepræst, dr. theol.«

Alle kom derefter ret hurtigt hjem - uden dom (!?) ${ }^{41}$. Kun Chr. Riggelsen holdtes tilbage vinteren over, efter mit skøn virkelig uberettiget, måske efter personligt bestemte ønsker af tidligere fæller i sognerådet. Tilsidst underskrev alle i Kummerlev en ansøgning om hans hjemsendelse. Jeg var et par gange på besøg i Faarhuslejren, hvor jeg kendte både lederen kaptajn Bartholdy ${ }^{42}$ og præsten Gadeberg. Da jeg den første gang med vagtledsagelse fra porten til kontoret undervejs fik øje på et par internerede fra Borg, tog disse hatten af for mig, mens jeg smilte til gengæld. Det blev øjeblikkeligt forbudt af vagtmanden. Ingen som helst kontakt med de internerede! Jeg fik dog næste gang tilladelse til en privat samtale med Riggelsen. Det viste sig - desværre -, at 
Faarhuslejren kom til at virke som et tysk højskoleophold for de pågældende med foredrag og recitationer, f.eks. ved frimenighedspræst G. Horstmann og andre, og dermed skabte et fast tysk kammeratskab, som stadig dyrkes. Da f.eks. en ung Faarhus-mand fra Højst sogn et par år senere købte ejendom i sognet og jeg besøgte ham, udtalte han sig åbent imod alle præster undtagen pastor Schau, Højer, som han havde været interneret sammen med. »Han er kammerat «, sagde han. Ham havde han respekt for og tillid til. ${ }^{43}$ Som præst havde jeg afslået at være beskikket tilsynsførende for de hjemsendte internerede fra Brede sogn, hvad nok har vist sig at være rigtigt.

$25 / 8$ skrev jeg i »Hejmdal« en artikel om »dommen ved Holsted ret« over den unge Jens Andersen fra Bredebro som for hård mod en ung krigsdeltager, der wikke vidste hvad han gjorde«. Dommen var den første af sin art og nok tænkt som en prøveballon. Straffen på $21 / 2$ år blev da også nedsat, med benådning til sidst. ${ }^{44}$ Min nabo, læge Schultz, gav mig i den anledning i telefonen en grov overhaling, at jeg ville tage »mordere« $i$ forsvar. Han var vel talerør for den chauvinistiske fløj indenfor modstandsbevægelsen, der også viste revolverbevæbnede præster efter $5 / 5$. Jeg ville være Kristi og det sande Danmarks sendebud.

17/10 45 deltog jeg da også i folketingsmand Erik Appels møde med de loyale hjemmetyskere på »Ellehus« for at drøfte de fremtidige dansk-tyske forhold i Grænselandet.

I besættelsestiden førtes det danske folks kamp for sandhed og ret, frihed og selvstændighed, menneskelighed og folkestyre til sejr. Det nationalistiske retsopgør bagefter fornægtede vore bedste folkelige traditioner.

\section{OM UDGIVELSEN}

Ovenstående er en let bearbejdet udgivelse af Jens Holdts manuskript $» B r e d e$ sogn under besættelsen. En dokumentarisk skildring «. Manuskriptet er efter publiceringen indgået i Jens Holdts privatarkiv i Landsarkivet for Sønderjylland. Sammested findes supplerende materiale (manuskripter og korrespondance) til belysning af de behandlede emner.

I forbindelse med udarbejdelsen af noterne er desuden benyttet en upubliceret beretning af kaptajn P. M. Digmann (Frøslevlejrens Museums arkiv).

I øvrigt henvises til supplerende materiale i Lokalhistorisk Samling, Bredebro. 


\section{LITTERATUR}

Henrik Becker-Christensen: "Det tyske mindretal i Nordslesvig 1920-32«, bd. I-II. Institut for Grænseregionsforskning 1990.

H. Hejselbjerg Paulsen: Nekrolog over Jens Holdt, Sønderjyske Årbøger 1967.

Henrik Skov Kristensen m.fl.: "Vestallierede luftangreb i Danmark under 2. verdenskrig«, bd. I-II. Aarhus Universitetsforlag 1988.

Henrik Skov Kristensen: »Modstandsbevægelsen på Skærbæk-egnen 1944-45«, Sønderjyske Årbøger 1993.

Henrik Skov Kristensen: »Fangeselvstyret i Frøslevlejren«, Siden Saxo nr. 3, 1994.

Henrik Skov Kristensen: „Frøslevlejren - museum eller feriehotel?«, Fortid og Nutid nr. 4, 1994.

Henrik Skov Kristensen: "Grænsen og besættelsen« i „Grænsen 75 år «. Institut for grænseregionsforskning \& Told- og skattehistorisk selskab, 1995.

Iver Møller: „Træk fra kapitulationen og retsopgøret i Sønderjylland «, Sønderjyske Årbøger 1992. Johan Peter Noack: "Det tyske mindretal i Nordslesvig under besættelsen«, Munksgaard 1975.

Statistisk Årbog, 1939.

Ditlev Tamm: »Retsopgøret efter besættelsen«. Jurist- og Økonomforbundets Forlag, 1984.

Erik Thostrup Jacobsen: "Som om intet var hændt - Den danske folkekirke under besættelsen«. Odense Universitetsforlag 1991.

Aage Trommer: "Modstandsarbejde i Nærbillede«. Odense Universitetsforlag 1973.

\section{NOTER}

1. DNSAP fik 4,7\% i Sønderjylland ved Rigsdagsvalget i 1939. På landsplan fik partiet 1,8\%. 15.016 stemte hjemmetysk ved Rigsdagsvalget. Det svarede til $14,6 \%$ af de afgivne stemmer i Sønderjylland. Med 5,3\% tyske stemmer var Brede altså ikke nogen tysk højborg.

2. Her refererer Jens Holdt til Hitlers »heim ins Reich« politik, hvis mål var at genindlemme de landområder, som Tyskland havde måttet afstå ved Versailles-traktaten efter 1. Verdenskrig. Doktrinen blev i flere tilfælde omsat til praksis i sidste halvdel af 30erne.

3. Lige siden den 9.april har der været allehånde rygter og gisninger mht. til det tyske mindretals forhåndsviden om den forestående tyske indmarch. Hidtil er der ikke fundet kildebelæg for disse rygter og gisninger. De hjemmetyske motorcyklister, som allerede aftenen før angrebet skulle have gennemkørt ruten, har tydeligvis også sit udspring i et rygte.

4. Besættelsen medførte en udbredt forventning i det tyske mindretal om en grænserevision. Besættelsesmagten prioriterede dog den politiske stabilitet i Danmark højere. Umiddelbart efter den 9. april gjorde man derfor mindretallet klart, at grænsen, i hvert fald foreløbig, lå fast.

Imidlertid blev de hjemmetyske forhåbninger hurtigt vakt igen. Den 16.juni 1940 talte mindretallets »fører« Jens Møller på et møde for partiets underførere i Tinglev. Her indskærpede han bl.a., at det var forbudt at flage med hagekorsflag - men føjede så i øvrigt til, at det i hvert fald ikke måtte ske før den 28. juni. Møllers bemærkning blev straks opfattet af tilhørerne som et vink om, at der denne dato, Versailles-dagen, ville ske noget ganske afgørende. Derfor købte mange hjemmetyskere hagekorsflag, som skulle vaje på den store dag.

Forventningerne led dog et nyt og afgørende knæk den 25. juni, da en kort notits fra partiledelsen i den hjemmetyske avis indskærpede, at det var forbudt at flage med hagekorsflag. Notitsen blev bragt på Berlins foranledning.

5. "Modstandsfront" betegner her blot den nationale samling mod tyskheden og nazismen. Om modstandsarbejde i gængs forstand var der ikke tale.

6. Clearingkontoen var et instrument i den dansk-tyske samhandel. På trods af betydelige tyske leverancer til Danmark blev samhandelen skæv med Danmark som den største leverandør. Det danske tilgodehavende blev derfor udbetalt af den danske Nationalbank over clearingkontoen. Med andre ord, Nationalbanken, dvs. den danske statskasse, mlagde ud« for tyskerne, som dog aldrig betalte regningen. I 1945 var kontoen vokset til 3 milliarder $\mathrm{kr}$. 
På samme måde lagde Nationalbanken ud for tyskerne, når danske virksomheder skulle betales for bygningsarbejder for besættelsesmagten. Det foregik over den såkaldte Værnemagtskonto, som i 1945 var vokset til 5 milliarder $\mathrm{kr}$.

7. Med »krisen« refererer Holdt uden tvivl til landbrugskrisen i 30erne. Når Holdt fremhæver, at fru Ratenburg havde fået et dansk hypoteklån i sin ejendom, berører han indirekte »Kreditanstalt Vogelgesangs« virksomhed i Nordslesvig. Kreditanstalten blev oprettet i 1926 af advokat Georg Vogelgesang i Haderslev og var et led i det tyske mindretals »jordkamp«. Med rigstysk kapital i ryggen forsøgte Kreditanstalt Vogelgesang via lån til hjemmetyske landmænd at få så meget jord på hjemmetyske hænder som muligt.

Imidlertid var kreditanstaltens kapital begrænset. Derfor var hjemmetyskere ofte henvist til at optage danske hypoteklån. Af Holdts skildring kunne man få det indtryk, at dette både var usædvanligt og vanskeligt, hvilket ikke var tilfaldet.

8. "At slibe spade« henviser til, at det danske nazistpartis såkaldte "Stormafdeling « forberedte sig på en offensiv. Partiets stormtropper var udover deres specielle uniformering karakteristiske derved, at de havde skarpslebne spader som personlige våben. Efter galdende dansk lov måtte de ikke bære skydevåben.

Netop i efteråret 1940 kulminerede DNSAP's bestræbelser på at komme til magten i Danmark. Det berømte »spadeslag i Haderslev« den 8 . december skal ses i denne sammenhæng. Tyskerne støttede dog aldrig helhjertet DNSAP's stormløb mod den danske samlingsregering.

9. $\mathrm{SA}=$ Stormafdeling (DNSAP).

10. Igen må understreges, at når Holdt taler om »modstandsfront«, skal den forstås som en national/ pro-parlamentarisk front vendt mod tyskheden og nazismens anti-parlamentariske ideologi. "Modstandsfronten « omfatter for Holdt altså også samlingsregeringens partier, som stod bag forhandlings- og samarbejdspolitikken overfor den tyske besættelsesmagt. Hal Koch var som leder af »Dansk Ungdoms Samvirke» en af de fremtrædende skikkelser i denne front.

11. »Belästigung« var et begreb, som den hjemmetyske ledelse tog $\mathrm{i}$ anvendelse $\mathrm{i}$ den politiske kamp for en grænserevision. Ved at indberette danske 'chikaner' til tyskerne håbede man at nå det forjattede mål.

12. Kirkekampen i Norge havde baggrund i de besættelsespolitiske forhold her. Den norske konge og regering var flygtet til England, hvorfra de fortsat udøvede statssuveræniteten. Tyskerne oprettede i Norge et Reichskommissariat, erklærede kongen for afsat og lod de norske nazister få indflydelse som konstituerede statsråder. Det tvang den norske kirke ud $\mathrm{i}$ en stadig hårdere opposition til øvrigheden, kulminerende med at man i foråret 1942, efter Quislings totale magtovertagelse, brød med den norske stat. Den norske søsterkirkes kamp fulgtes nøje i danske kirkelige kredse.

13. Af Holdts beskrivelse kunne man få det indtryk, at der var tale om planlagte angreb. Angrebene skyldtes imidlertid fejlnavigation. Flybesætningerne troede, at de var over Niebüll. Se nærmere Henrik Skov Kristensen m.fl. bd.I, s. 280-85.

14. Som følge af den omfattende krigsindsats henvendte chefen for den tyske grænsebevogtning sig mod slutningen af 1942 til Jens Møller for at hverve hjemmetyskere til den tyske grænsebevogtningstjeneste. Hvervningen rettede sig mod mand, som af den ene eller anden årsag ikke var kommet i egentlig tysk militærtjeneste. De hvervede skulle bære den tyske toldtjenestemandsuniform, uden militærarmbind. I tjenesten skulle man bære våben, som dog skulle aflægges, når grænsen blev passeret. At arbejdet blev regnet for krigsindsats har sikkert været medvirkende til, at Jens Møller gav hvervningen sin velsignelse. I januar 1943 var de første 13 hjemmetyskere antaget, mod årets slutning drejede det sig om 75 , og ved årsskiftet $1944-45$ var 89 fra den tyske folkegruppe ansat ved den tyske toldgrænsebevogtning.

15. Sabotageaktionen i Tønder den 1.61943 blev udført af en kommunistisk gruppe under læge Ejnar Dahl. Gruppen var blevet sat igang af Hans Peter Poulsen, der organiserede DKP's illegale arbejde i Esbjerg.

16. Det kan ikke afvises, at nogle selvbestaltede danske nazister i deres SA-uniformer har følt sig foranlediget til at udøve en myndighed under uroen. Mere sandsynligt er det dog, at de pågaldende var nogle hjemmetyskere fra SK(=Schleswigsche Kameradschaft). Under alle omstændigheder synes Holdts udsagn vedr. SA-mændene at være baseret på en hjemmelsmand. 
17. Patruljerne bestod sandsynligvis af Zeitfreiwillige, som i flere tilfælde forrettede patruljetjeneste under urolighederne i august 1943. Iøvrigt et forhold, som var stærkt inkriminerende for korpsets medlemmer under retsopgøret.

18. I forbindelse med den militære undtagelsestilstand den 29. august 1943 overfaldt og afvæbnede tyskerne den danske hær og flåde. Herved blev 23 danske dræbt.

19. Holdts og Magles drøftelse med biskoppen havde baggrund i et initiativ, som sognepræsten ved Jesuskirken i København, Thorkild Glahn, tog den 31. august 1943, umiddelbart efter den danske regerings afgang den 29. august. Initiativet blev til »Præsternes uofficielle forening«. Tanken med initiativet var at skabe et meldesystem, der kunne fungere som alternativ til den officielle kirkelige struktur i påkommende tilfælde. Organiseringen skulle spredes ud over landet, og formålet var at skaffe pålidelige oplysninger og sikre, at de hurtigt kunne spredes blandt præsterne. Et andet formål var at sikre ensartet og samlet kirkelig optræden over for evt. tyske krav.

"Præsternes uofficielle forening«, "Puf«, kom til at omfatte næsten alle landets præster, og de betalte ca. $1 \%$ af deres løn til at understøtte f.eks. præster, som var kommet i vanskeligheder på grund af modstandsarbejde.

Foreningen blev ganske vist organiseret illegalt, men nogen illegal modstandsorganisation i egentlig forstand blev den aldrig. Det nærmeste Puf kom på alvorlige illegale aktiviteter var, at man fra efteråret 1944 stod modstandsorganisationen 'Ringen' bi med at etablere flugtruter for nedstyrtede allierede flyvere.

20. Denne sabotage-aktion blev udført af en gruppe, som var blevet organiseret af ingeniør Bøge i Tønder. Bøge, som var tilknyttet partiet "Dansk Samling«, var dynamoen i sabotagearbejdet i Tønder og omegn i sensommeren og efteråret 1943. Aktionerne blev udført med effektivt sprængstof leveret af den engelske SOE-organisation.

21. Da det mod slutningen af september 1943 blev klart, at det trak op til en tysk aktion mod de danske jøder, afleverede Københavns biskop Fuglsang-Damgaard på biskoppernes vegne den 29. september en protest stilet til Dr. Best. Da det gennem dagbladene lordag 2.oktober blev kendt, at aktionen havde fundet sted, blev protesten gennem Puf (se note 19) udsendt $i$ løbet af dagen til praktisk taget alle landets præster og næste dag oplæst $i$ de fleste kirker.

Det er ikke helt korrekt, når Holdt karakteriserer protesten som »biskoppernes fælles hyrdebrev«, for Fuglsang-Damgaard havde ikke taget sine bispekolleger i ed. Det var nogle af dem noget fortørnet over.

22. Pastor Hans Jacob Helms i Mjolden-Randerup var tidligt aktiv indenfor modstandsorganisationen "Ringen«, og tog del i det senere illegale arbejde på Skærbæk-egnen. Bl.a. husede han SOE-agenten $»$ Per«, som virkede i Region III.

23. Præsten i Skærbæk handlede sådan set i overensstemmelse med biskop Scharlings retningslinier vedr. jøde-hyrdebrevet. Scharling pålagde nemlig ikke sine præster oplæsningen af hyrdebrevet som en embedspligt, men nøjedes med at henstille, at præsten gjorde menigheden bekendt med skrivelsen på den måde, den pågældende præst fandt rigtigst.

Af Holdts beskrivelse kunne man få det indtryk, at pastor Hansens nationale sindelag var blakket. Det er der absolut intet belæg for. Men pastor Hansen hørte ikke til blandt de mere aktivistiske præster, som iøvrigt udgjorde et fåtal.

24. Pastor Harald Sandbrk var barthiansk inspireret og medlem af partiet Dansk Samling, som var en dynamo $i$ den danske modstandsbevægelse. På tidspunktet for mødet $i$ Dalum var Harald Sandbæk »under jorden« og stærkt eftersøgt som aktiv sabotør.

25. Regin Prenter var professor i teologi ved Ảrhus Universitet. Flyvebladet, som Holdt nævner, havde titlen »Kirken og Retten«. Det udkom i 20.000 eksemplarer, udgivet af det illegale Dansk Samling-blad »Folk og Frihed«. Synspunkterne i pjecen var så aktivistiske, at de ikke vandt genklang i bredere kirkelige kredse.

26. "Deutscher Selbstschutz Nordschleswig« blev oprettet i begyndelsen af 1944 under ledelse af Peter Larsen. Korpset skulle angiveligt beskytte det tyske mindretal mod sabotage, terror og trusler. Der rekrutteredes hovedsageligt blandt medlemmer af »Schleswigsche Kammeradschaft «, SK. 》Selbstschutz《 bar SK-uniform og var bevæbnet med pistol.

27. I hyrdebrevet tog kirken generelt afstand fra krigens forråelse, lovløsheden og blodsudgydelserne. 
Der var dog ingen tvivl om, at hyrdebrevet sigtede til den tyske terror, for mordet på »vor store digter, en uforfærdet kirkens mand « blev næunt specifikt. Hyrdebrevet opfordrede endvidere til bøn for dem, "som lider under vold og uret, for alle, som har mistet deres frihed, for vore bortførte landsmand, for dem, som ved krigens gang er skilt fra deres hjem og os«. Endvidere blev der udtrykt ønske om, at »den folkelige og nationale enhedsfront« ikke blev brudt.

28. Organisation Todt, opkaldt efter Fritz Todt, var en halvmilitær organisation, som udførte militære bygningsopgaver. Efter Fritz Todts død i 1942 overtog rustningsminister Speer ledelsen af organisationen.

29. Med »tysk hjemmeværn« menes "Zeitfreiwillige«. Det folkelige udtryk for de tidsfrivillige var "Heimwehr«.

30. Under besættelsen etableredes en lang række uniformerede danske vagtkorps af mere eller mindre militær karakter. De mest kendte var »Sommerkorpset«, opkaldte efter lederen Poul Sommer, og »marinevægterkorpset«. Sommerkorpset udførte bevogtningstjeneste for Luftwaffe, marinevægterne for Kriegsmarine.

Hjemmetyskerne lod sig især hverve til »Schwerinervagtkorpset«. Det var et privat tysk vagtkorps, som udførte vagttjeneste på tyske flyvepladser i Jylland. Medlemmerne var iført en sort uniform og bevæbnet med pistol eller karabin.

31. Strejkerne og butikslukninger i landsdelen skyldtes, at ca. 200 Frøslev-fanger, stik mod alle aftaler, blev deporteret til tysk KZ-lejr den 15.9.

32. Interneringen af det danske politi og grænsegendarmerne den 19.9. skete på foranledning af chefen for det tyske politi i Danmark, Günther Pancke.

33. Der refereres sandsynligvis her til bl.a. sabotageaktioner mellem Tønder og Visby station, samt på selve Visby station. Aktionerne blev udført af grupper fra Tønder.

34. Pastor Magles arrestation skyldtes ikke hans engagement i Puf, men hans illegale arbejde i organisationen $\gg$ Ringen $\ll$.

35. Personen fra Astrup (Bjerrum) kan kun være landmand Hans Jessen Bjerrum i Søndernæs. Han kom fra årsskiftet 1944-45 til at udgøre en veritabel eenmandshær i den nordlige del af Skærbæk distrikts modstandsbevægelse. Bjerrum var nærmest desperat for at komme i lag med tyskerne, og hans aktioner fra marts 1945, som bl.a. omfattede jernbanesabotager og afvæbning af tyske soldater i fuldt dagslys, var dumdristige, grænsende til det dumdristige. Ledelsen i Skærbæk var ikke altid helt rolig ved Bjerrums aktions-former.

36. Se note 30. Sandsynligvis tilknyttet den tyske flyveplads i Skrydstrup.

37. Der må refereres til skinnesprængninger mellem Døstrup og Skærbæk den 3.3. Aktionen var debutten for jernbanesabotørerne i Skærbæk distrikt.

38. Slusen ved Ballum blev lukket for at skabe oversvømmelser, som kunne hæmme en allieret fremrykning.

39. Den 23. april skulle 150 Lancaster-bombefly udføre et dagangreb mod havneområdet i Flensborg. Over selve målet blev angrebet dog afblæst på grund af dårligt vejr. Jagereskorten var imidlertid opsat på at få noget ud af turen, så den fortsatte nordpå og udførte angreb på trafik nord for grænsen. Jagerbesætningerne rapporterede at have angrebet »stabsvogne og lastbiler" bl.a. på »en vej øst for Ribe«. Af danske kilder fremgår, at to organisation Todt-vogne blev beskudt. En blev ødelagt.

40. Det lyder troligt, at en del af de internerede hjemmetyskere endnu ikke mod slutningen af juli 45 havde været i grundlovsforhør. Skønsmæssigt blev ca. 3.000 hjemmetyskere interneret i Faarhuslejren, og selv om dommer, anklager og forsvarer arbejdede på højtryk i Faarhuslejrens retslokaler, kunne man ikke afvikle mere end ca. 30 grundlovsforhør pr. dag.

41. Såfremt Holdts udråbs- og spørgsmålstegn i parentes er udtryk for egen tvivl eller forundring, er de velanbragte:

Hvis de i brevet nævnte personer virkelig havde været vagtmænd og Zeitfreiwillige, forekommer det usandsynligt, at de er blevet løsladt fra interneringen i løbet af 1945 . Hvis vi koncentrerer os om de Zeitfreiwillige, kom de første sager for retten så sent som i foråret 1946. I den mellemliggende periode forblev medlemmerne af korpset internerede/varetægtsfængslede.

Meget tyder på en erindringsforskydning hos Holdt. 
42. Kaptajn Bartholdy var kommandant i Fårhuslejren fra begyndelsen af juli 45 indtil det danske fængselsvæsen overtog administrationen af lejren i august 1945. For Bartholdy havde kaptajn P. M. Digmann været lejrkommandant. Begge lejrkommandanter var tidligere fanger i Frøslevlejren, og begge havde haft fremtrædende poster i Frøslevlejrens fange-selvstyre. Digmann kom til at lægge retningslinierne for Fårhuslejrens drift. Og han valgte at anvende nøjagtig samme "Hausordnung" og "Strafordnung", som tyskerne havde anvendt i Frøslevlejren. Blot blev retningslinierne i Fårhusperioden, som Digmann har anfort det $i$ en beretning, fulgt til punkt og prikke. Dertil kommer, at som erfarne fanger kunne de første Fårhuskommandanter tage mange "fangefiduser « $i$ opløbet. Forholdene i Fårhuslejren var derfor generelt mere præget af kadaverdisciplin end forholdene i Frøslevlejren. Til gengæld behøvede Fårhusfangerne ikke konstant at frygte en livstruende deportation.

43. Der er en slående principiel lighed mellem Fårhus- og Frøslevfangernes aktiviteter og kammeratskab.

44. I begyndelsen af retsopgøret tog de lavere retter i strafudmålingen ikke særlige hensyn til det tyske mindretals specielle situation. Men den $29.61946 \mathrm{kom}$ der en ændringslov til det straffelovstillæg, efter hvilket landssvigerne blev dømt, som fik betydning for det tyske mindretal. Der blev nu mulighed for at lade straffen gå ned til fengsel i 30 dage, wnår gerningsmanden har begået det strafbare forhold under indflydelse af en særlig pression eller påvirkning gennem opdragelse eller på grund af en på ung alder beroende umodenhed, eller der $\mathrm{i}$ øvrigt $\mathrm{i}$ de forhold, hvorunder han er opvokset, foreligger undskyldende momenter ... «

Det betød, at gennemsnitsdommen for hjemmetyskere, som havde udført fronttjeneste, kom til at ligge på ca. 1 års fængsel. 
